\title{
Ni ENRICHMENT AND STABILITY OF Al-FREE GARNIERITE SOLID-SOLUTIONS: A THERMODYNAMIC APPROACH
}

\author{
S. Galí $i^{1} *$, J. M. Soler ${ }^{2}$, J. A. Proenza ${ }^{1}$, J. F. Lewis ${ }^{3}$, J. Cama $^{2}$, And E. Tauler ${ }^{1}$ \\ ${ }^{1}$ Department of Crystallography, Mineralogy and Mineral Deposits, Faculty of Geology, University of Barcelona, \\ C/ Martí i Franquès S/N, 08028, Barcelona, Catalonia, Spain \\ ${ }^{2}$ Institute of Environmental Assessment and Water Research, IDAEA, CSIC, Jordi Girona 18-26, 0803, Barcelona, Catalonia, \\ Spain \\ ${ }^{3}$ Department of Earth and Environmental Sciences, The George Washington University, Washington, D.C. 20052 USA
}

\begin{abstract}
Garnierites represent significant Ni ore minerals in the many Ni-laterite deposits worldwide. The occurrence of a variety of garnierite minerals with variable Ni content poses questions about the conditions of their formation. From an aqueous-solution equilibrium thermodynamic point of view, the present study examines the conditions that favor the precipitation of a particular garnierite phase and the mechanism of Ni-enrichment, and gives an explanation to the temporal and spatial succession of different garnierite minerals in Ni-laterite deposits. The chemical and structural characterization of garnierite minerals from many nickel laterite deposits around the world show that this group of minerals is formed essentially by an intimate intermixing of three Mg-Ni phyllosilicate solid solutions: serpentine-népouite, kerolite-pimelite, and sepiolite-falcondoite, without or with very small amounts of $\mathrm{Al}$ in their composition. The present study deals with garnierites which are essentially Al-free. The published experimental dissolution constants for $\mathrm{Mg}$ end-members of the above solid solutions and the calculated constants for pure $\mathrm{Ni}$ end-members were used to calculate Lippmann diagrams for the three solid solutions, on the assumption that they are ideal. With the help of these diagrams, congruent dissolution of Ni-poor primary minerals, followed by equilibrium precipitation of Ni-rich secondary phyllosilicates, is proposed as an efficient mechanism for $\mathrm{Ni}$ supergene enrichment in the laterite profile. The stability fields of the solid solutions were constructed using $\left[\log a_{\mathrm{SiO}_{2}(\mathrm{aq})}, \log \left(\left(a_{\mathrm{Mg}^{2+}}+a_{\mathrm{Ni}^{2+}}\right) /\left(a_{\mathrm{H}^{+}}\right)^{2}\right)\right]$ (predominance) diagrams. These, combined with Lippmann diagrams, give an almost complete chemical characterization of the solution and the precipitating phase(s) in equilibrium. The temporal and spatial succession of hydrous MgNi phyllosilicates encountered in Ni-laterite deposits is explained by the small mobility of silica and the increase in its activity.
\end{abstract}

Key Words - Garnierites, Kerolite-Pimelite, Ni-laterite, Sepiolite-Falcondoite, Serpentine-Népouite, Stability.

\section{INTRODUCTION}

Nickel laterites are regolith materials derived from ultramafic rocks (Trescases, 1975; Golightly, 1981; Brand et al., 1998). Weathering of the rocks results in enriched horizons, so that minor elements such as $\mathrm{Ni}, \mathrm{Co}$, and $\mathrm{Mn}$ contained in the unaltered parent rock become enriched in the laterite profiles (Brand et al., 1998; Freyssinet et al., 2005; Golightly, 2010). An iron cap (ferricrete or duricrust) is often found at the top of the weathering profile and the cap grades downward through a transitional zone of limonite to a saprolite zone transitional into bed rock. Saprolite is a zone of rapid change and of maximum supergene enrichment of nickel. The protolith or bedrock is mainly dunite, harzburgite, or lherzolite and their serpentinized equivalents.

Following Golightly (1981), Ni laterites are developed from: (1) unserpentinized peridotite (e.g. Poro,

\footnotetext{
* E-mail address of corresponding author: gali@ub.edu
}

DOI: $10.1346 / C C M N .2012 .0600203$
New Caledonia; Soroako West, Indonesia); (2) partially serpentinized peridotite (e.g. Falcondo Mine, Dominican Republic); or (3) totally serpentinized parent rock (e.g. Bonsora, Soroako East, Indonesia). As an example, selected analyses for the most important primary Ni-carrying minerals at Falcondo (Table 1) indicate that these minerals are mainly olivine and 'oceanic' serpentine. The fate of $\mathrm{Ni}$ can be tracked through the different values of the atomic ratio of $\mathrm{Fe} / \mathrm{Ni}$ in these minerals. Initially, in olivine, $\mathrm{Fe} / \mathrm{Ni} \approx 19$. In oceanic serpentines this value is slightly smaller, indicating that some of the $\mathrm{Fe}$ is relocated in other phases like maghemite, which is readily hydrated to goethite. Goethite is able to incorporate or attach Ni (Manceau et al., 2003). The nickel contained in the limonite horizon and in primary serpentines is transferred to percolating meteoric solutions, and moves downward through the profile, being concentrated with $\mathrm{Si}$ and $\mathrm{Mg}$ within the underlying saprolite horizon to form secondary $\mathrm{Ni}$-enriched phyllosilicates.

In many Ni lateritic deposits of the hydrous silicate type, the lower saprolite is the ore horizon, and the ore minerals are mainly nickeloan varieties of serpentine, 
Table 1. Selected analyses of primary minerals in the parent rock of the Falcondo Ni-laterite deposit (Dominican Republic). Chr: accesory chromite, Ol: olivine, Opx: orthopyroxene, Cpx: clinopyroxene, and Srp: oceanic serpentine.

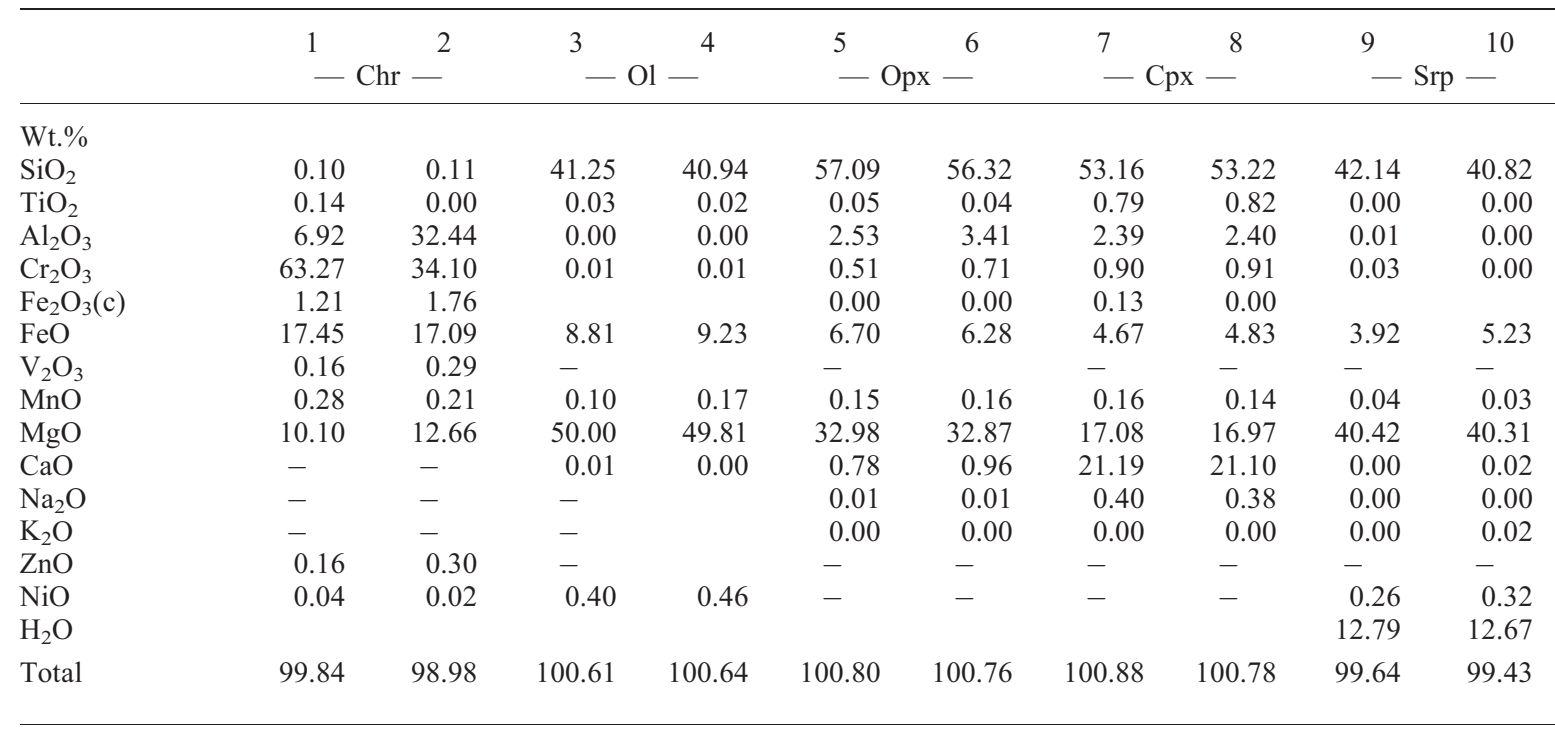

talc, sepiolite, chlorite, or smectites, many of which are poorly defined and informally named "garnierites" (e.g. Brindley and Hang, 1973; Springer, 1974; Pelletier, 1983). Garnierite is generally used as a field term referring to a wide variety of Ni-bearing hydrous silicates with a characteristic green color (e.g. Gleeson et al., 2003). When only small amounts of $\mathrm{Al}$ are present in the protolith, garnierites can be formed by different combinations of the three main $\mathrm{Mg}-\mathrm{Ni}$ solid solutions with serpentine, talc, and sepiolite-like structures; clays (chlorites and smectites) being absent (Wells et al., 2009; Tauler et al., 2009; Villanova-de-Benavent et al., 2011a).

Garnierites occur filling fractures, featureless voids, and cavities or as interstitial veins in the joints separating serpentine blocks, most commonly in the lower part of the saprolite horizon. Often, they have been removed from their original emplacement and have accumulated in cavities, forming breccias (Cluzel and Vigier, 2008). The most common and most studied occurrences of garnierites are found in the less serpentinized ophiolite-related peridotites of mantle origin as in New Caledonia (Trescases, 1975; Wells et al., 2009) and in the Caribbean (Gleeson et al., 2003; Lewis et al., 2006).

The progressive enrichment of $\mathrm{Ni}$ in the saprolite horizon occurs by means of two different processes. The dominant process is the direct replacement of preweathering minerals, such as olivine and serpentine, by $\mathrm{NiFe}$-enriched lizardites and by Ni-rich smectites. In the minerals formed by replacement, $\mathrm{Fe}$ and $\mathrm{Ni}$ increase at a percentage range (see Table 1). The second process involves the precipitation of $\mathrm{Mg}-\mathrm{Ni}$ phyllosilicates (Al-free garnierites) from aqueous solution. As described above, the garnierites form as fracture fillings, veins, and breccias. In contrast to the minerals formed by replacement, the garnierites are characterized by low $\mathrm{Fe}$ and are essentially free of Al. These garnierite minerals and the conditions of the precipitation process by which they form are the subject of the present study.

Here the authors explain, using equilibrium thermodynamics, three related, simultaneous phenomena: (1) supergene enrichment of $\mathrm{Ni}$ in a group of secondary phyllosilicates precipitating in Ni-laterite profiles Lippmann's diagrams (Lippmann, 1980) were found to be very helpful for this; (2) simultaneous precipitation of $\mathrm{Mg}-\mathrm{Ni}$-phyllosilicate solid solutions (in theory, up to three different s.s. \pm quartz) - this can be represented by an activity diagram proposed below; and (3) the spatial and temporal evolution of garnierites towards more silica-rich members, from serpentine to talc and sepiolite-type minerals, as has been described previously (e.g. Golightly, 1981; Freyssinet et al., 2005).

A simplified chemical system which is useful in the description of the stability relations among the $\mathrm{Ni}$-containing phyllosilicate phases consists of four components: $\mathrm{MgO}, \mathrm{NiO}, \mathrm{SiO}_{2}$, and $\mathrm{H}_{2} \mathrm{O}$. For aqueous solutions the basic species are: $\mathrm{Mg}^{2+}, \mathrm{Ni}^{2+}, \mathrm{SiO}_{2}(\mathrm{aq})$, $\mathrm{H}^{+}$, and $\mathrm{H}_{2} \mathrm{O}$. As garnierites are Fe-poor $(<0.5$ wt. $\% \mathrm{Fe})$ indicating a secondary origin (Pelletier, 1983; Manceau and Calas, 1985; Manceau et al., 1985; Proenza et al., 2008; Wells et al., 1999), Fe was not included in the system. Its inclusion would increase the complexity of the system without affording significant new information regarding the distribution of $\mathrm{Ni}$ among the main phases present. After weathering, residual Fe of the parent rock is concentrated in a highly insoluble limonitic horizon, formed mainly of goethite, hematite, and maghemite. 
This horizon is best defined by the complete disappearance of the primary silicates and is distinct from the heterogeneous saprolite below.

The Mg-Ni-phyllosilicates are members of three solid-solution series extending from $\mathrm{Mg}$ and $\mathrm{Ni}$ endmembers (e.g. Springer, 1974, 1976; Brindley et al., 1979; Gleeson et al., 2003; Tauler et al., 2009; Wells et al., 2009; Reddy et al., 2009; Villanova-de-Benavent et al., 2011b). The electron microprobe (EMP) analyses plotted in Figure 1 confirm this; a complete, stable solid solution between $\mathrm{Mg}$ and $\mathrm{Ni}$ end-members in the structures of these minerals must be possible at atmospheric temperatures and pressure.

Therefore, a complete solid solution between $\mathrm{Mg}$ and $\mathrm{Ni}$ end-members is a reasonable hypothesis. The terminology used here for the end-members, composition, and structure for the solid solutions are: serpentine $\left(\mathrm{Mg}_{3} \mathrm{Si}_{2} \mathrm{O}_{5}(\mathrm{OH})_{4}\right)$, népouite $\left(\mathrm{Ni}_{3} \mathrm{Si}_{2} \mathrm{O}_{5}(\mathrm{OH})_{4}\right)$; kerolite (or hydrated talc) $\left(\mathrm{Mg}_{3} \mathrm{Si}_{4} \mathrm{O}_{10}(\mathrm{OH})_{2} \cdot \mathrm{H}_{2} \mathrm{O}\right.$ ), pimelite (or hydrated willemseite) $\left(\mathrm{Ni}_{3} \mathrm{Si}_{4} \mathrm{O}_{10}(\mathrm{OH})_{2} \cdot \mathrm{H}_{2} \mathrm{O}\right)$; and sepiolite $\left(\mathrm{Mg}_{8} \mathrm{Si}_{12} \mathrm{O}_{30}(\mathrm{OH})_{4}\left(\mathrm{H}_{2} \mathrm{O}\right)_{4} \cdot 8 \mathrm{H}_{2} \mathrm{O}\right)$ falcondoite $\left(\mathrm{Ni}_{8} \mathrm{Si}_{12} \mathrm{O}_{30}(\mathrm{OH})_{4}\left(\mathrm{H}_{2} \mathrm{O}\right)_{4} \cdot 8 \mathrm{H}_{2} \mathrm{O}\right)$ (Brindley and Hang, 1973; Brindley and Maksimovic, 1974; Springer, 1974; Brindley and Wan, 1975; Brindley et al., 1979). Serpentine in saprolite can be present as a mixture of different structural varieties such as chrysotile, clinochrysotile, polygonal serpentine, and lizardite-1T. Indeed, in a single nanoscale particle, the transition between the different structural varieties can be observed using transmission electron microscopy (TEM) (Villanova-de-Benavent et al., 2011a). Kerolite and Ni-rich kerolite, a very fine-grained, hydrated variety of talc, is also present (Brindley et al., 1979; Soler et al., 2008).

Here, the published experimental dissolution constants for $\mathrm{Mg}$ end-members and the calculated constants for pure $\mathrm{Ni}$ end-members were used to calculate Lippmann diagrams for the serpentine-népouite, kerolite-pimelite, and sepiolite-falcondoite (Srp-Nep, KerPim, and Sep-Fal) solid solutions, on the assumption that they are ideal. In addition a particular activity diagram for the system $\mathrm{MgO}-\mathrm{NiO}-\mathrm{SiO}_{2}-\mathrm{H}_{2} \mathrm{O}$, delimiting the stability field of each Ni-bearing phyllosilicate and quartz, is proposed. Garnierites, as described below, can precipitate from aqueous solution in the form of one or two solid solutions, under near equilibrium conditions.

\section{THEORY}

The basic reactions involved in the formation or dissolution of $\mathrm{Mg}$ and $\mathrm{Ni}$ end-member silicates are given in Table 2. In the system $\mathrm{MgO}-\mathrm{NiO}-\mathrm{SiO}_{2}-\mathrm{H}_{2} \mathrm{O}$, under constant temperature and pressure, the maximum number of phases present in equilibrium is four. In the presence of an aqueous phase, three solid phases are in equilibrium for zero degrees of freedom. Hence, in garnierites, a maximum of either three solid solutions or two solid solutions plus quartz is expected to precipitate from solution under near-equilibrium conditions. However, the most frequent observation is the existence of equilibrium between two solids (two solid solutions or one solid solution and quartz), or simply a single solid

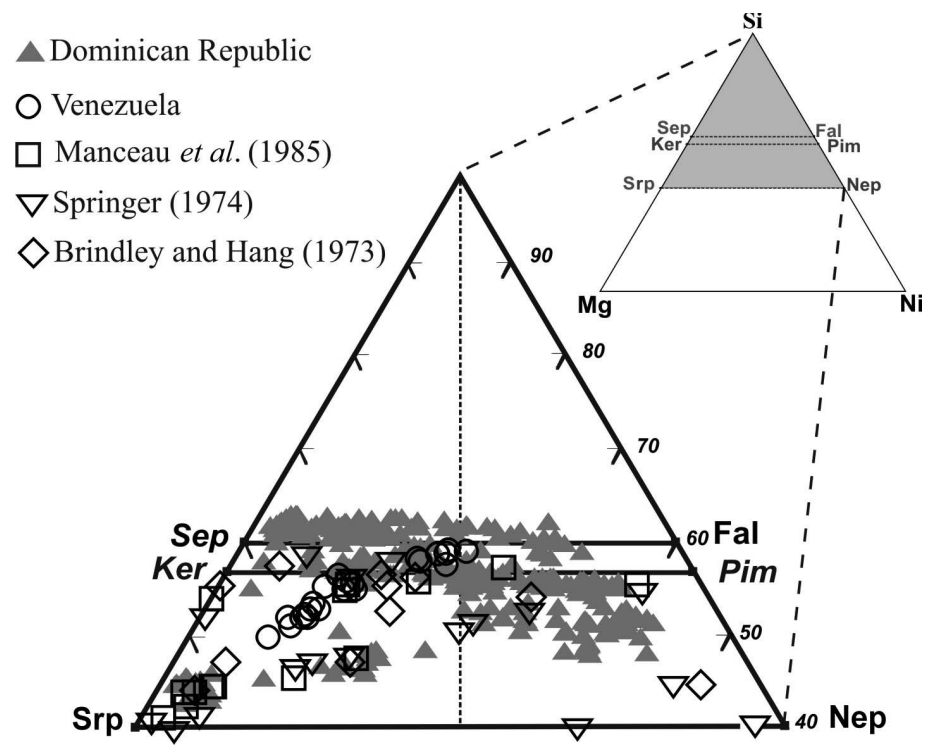

Figure 1. Projection of Caribbean garnierite ore compositions (Proenza et al., 2008; Tauler et al., 2009; Soler et al., 2010; Villanovade-Benavent et al., 2011 a, 2011b) and published data (Brindley and Hang, 1973; Brindley, and Wan, 1975; Springer, 1974, 1976; Manceau et al., 1985) for garnierites from different Ni-laterite deposits, in a Si-Ni-Mg ternary diagram (at.\%). The positions of the solid-solution series between Ni-sepiolite (Sep)-falcondoite (Fal), kerolite (Ker)-pimelite (Pim), and lizardite (Srp)-népouite (Nep) are also indicated. 
Table 2. Dissolution reactions for $\mathrm{Mg}$ and $\mathrm{Ni}$ end-members of garnierite, phyllosilicates, and quartz, labeled with the corresponding equilibrium constants used in the text.

Serpentine: $\mathrm{Mg}_{3} \mathrm{Si}_{2} \mathrm{O}_{5}(\mathrm{OH})_{4}+6 \mathrm{H}^{+}=3 \mathrm{Mg}^{+2}+2 \mathrm{SiO}_{2}(\mathrm{aq})+5 \mathrm{H}_{2} \mathrm{O}$

$\log \mathrm{K} 1(1)$

Népouite: $\mathrm{Ni}_{3} \mathrm{Si}_{2} \mathrm{O}_{5}(\mathrm{OH})_{4}+6 \mathrm{H}^{+}=3 \mathrm{Ni}^{+2}+2 \mathrm{SiO}_{2}(\mathrm{aq})+5 \mathrm{H}_{2} \mathrm{O}$

$\log \mathrm{K} 2(2)$

Kerolite: $\mathrm{Mg}_{3} \mathrm{Si}_{4} \mathrm{O}_{10}(\mathrm{OH})_{2} \cdot \mathrm{H}_{2} \mathrm{O}+6 \mathrm{H}^{+}=3 \mathrm{Mg}^{+2}+4 \mathrm{SiO}_{2}(\mathrm{aq})+5 \mathrm{H}_{2} \mathrm{O}$

$\log \mathrm{K} 3(3)$

Pimelite: $\mathrm{Ni}_{3} \mathrm{Si}_{4} \mathrm{O}_{10}(\mathrm{OH})_{2} \cdot \mathrm{H}_{2} \mathrm{O}+6 \mathrm{H}^{+}=3 \mathrm{Ni}^{+2}+4 \mathrm{SiO}_{2}$ (aq) $+5 \mathrm{H}_{2} \mathrm{O}$

Sepiolite: $\mathrm{Mg}_{8} \mathrm{Si}_{12} \mathrm{O}_{30}(\mathrm{OH})_{4}\left(\mathrm{H}_{2} \mathrm{O}\right)_{4} \cdot 8 \mathrm{H}_{2} \mathrm{O}+16 \mathrm{H}^{+}=8 \mathrm{Mg}^{+2}+12 \mathrm{SiO}_{2}(\mathrm{aq})+22 \mathrm{H}_{2} \mathrm{O}$

Falcondoite: $\mathrm{Ni}_{8} \mathrm{Si}_{12} \mathrm{O}_{30}(\mathrm{OH})_{4}\left(\mathrm{H}_{2} \mathrm{O}\right)_{4} \cdot 8 \mathrm{H}_{2} \mathrm{O}+16 \mathrm{H}^{+}=8 \mathrm{Ni}^{+2}+12 \mathrm{SiO}_{2}$ (aq) $+22 \mathrm{H}_{2} \mathrm{O}$

Quartz: $\mathrm{SiO}_{2}$ (quartz) $=\mathrm{SiO}_{2}(\mathrm{aq})$

that is a solid solution or quartz (e.g. Vitovskaya et al., 1969; Brindley and Hang, 1973; Springer, 1974; Golightly, 1981; Soler et al., 2008, and examples in the present study).

With the given reactions (Table 2), all possible combinations of phases can be examined in light of thermodynamic considerations, provided that the corresponding equilibrium constants are known. A brief account of the equilibrium constants used was necessary, before the different combinations of phases in the system were reviewed. The most problematic choice was for the equilibrium constant of reaction (1) (Table 2), ( $\log \mathrm{K} 1$ value). Several $\log \mathrm{K}$ constants for the dissolution of serpentine are found in the literature (Table 3), and most are controversial because of the different crystal structures of serpentines and the close proximity of these structures in the same sample (Evans, 2004). The various equilibrium constants were calculated from the respective free energies of formation (Table 4). The value of $\log \mathrm{K} 1$ (for reaction 1) was constrained by the experimental observation that at equilibrium Ni-kerolitie was more enriched in Ni than Ni-serpentine. The log K1 value that best fits the observed compositions of this equilibrium is the one derived from $\Delta G_{\text {serpentine }}$ given by Bricker et al. (1973). Constant values for $\mathrm{Mg}$ endmembers of kerolite and sepiolite ( $\log \mathrm{K} 3$ and $\log \mathrm{K} 5)$

Table 3. Reported and calculated $\log \mathrm{K}$ values.

\begin{tabular}{|c|c|c|c|}
\hline Structure & $\Delta G_{\mathrm{f}}(\mathrm{kJ} / \mathrm{mol})$ & $\log \mathrm{K}$ & Reference \\
\hline \multicolumn{4}{|l|}{ Serpentine minerals } \\
\hline Chrysotile & -4037.02 & 31.86 & Helgeson et al. (1978) \\
\hline Serpentine & -4038.25 & 31.64 & Golightly (1981) \\
\hline Chrysotile & -4042.64 & 30.87 & Mel'nik (1972) \\
\hline Chrysotile & -4027.07 & $33.60 \pm 0.41$ & Bricker et al. (1973) \\
\hline Chrysotile & -4038.96 & 31.51 & Hostetler and Christ (1968) \\
\hline Nepouite & $\begin{array}{l}-2866.69 \\
-2883.20\end{array}$ & $\frac{21.4688}{18.58}$ & $\begin{array}{l}\text { This work, from Nriagu (1975) } \\
\text { Golightly (1981) }\end{array}$ \\
\hline \multicolumn{4}{|l|}{ Talc structure } \\
\hline Well crystallized & -5524.9 & 21.73 & Helgeson et al. (1978) \\
\hline Poorly crystallised & -5504.4 & 25.33 & Tardy and Duplay (1992) \\
\hline Kerolite & -5736.70 & $25.79 \pm 0.24$ & Stoessell (1988) \\
\hline \multirow[t]{2}{*}{ Pimelite } & -4591.24 & 11.46 & Tthis work, from Nriagu (1975) \\
\hline & -4594.67 & $\overline{10.85}$ & Golightly (1981) \\
\hline Sepiolite & -4271.61 & 15.53 & from Christ et al. (1973) \\
\hline Sepiolite & -4387.05 & $15.76^{*}$ & Stoessell (1988) \\
\hline Falcondoite & -3505.36 & $6.1565 *$ & This work, from Nriagu (1975) \\
\hline
\end{tabular}

* These constants correspond to the formula of sepiolite used by Stoessell, based on two octahedral cations. The underlined $\log \mathrm{K}$ values were used in the present work. 
Table 4. Free energies of formation used in the approximations of $\Delta G_{\mathrm{f}}$ of the minerals listed in Table 3 and in the derivation of the corresponding $\log \mathrm{K}$ of dissolution $\left(\mathrm{kJ} \mathrm{mol}^{-1}\right)$.

\begin{tabular}{lccl}
\hline Species & $\Delta G_{\mathrm{f}}(\mathrm{kJ} / \mathrm{mol})$ & Uncertainty & \multicolumn{1}{c}{ Reference } \\
\hline $\mathrm{Mg}(\mathrm{OH})_{2}$ & -846.034 & 0.3 & Helgeson (1969) \\
$\mathrm{Ni}(\mathrm{OH})_{2}$ & -459.266 & 0.2 & Tardy and Garrels $(1974)$ \\
$\mathrm{Si}(\mathrm{OH})_{4}$ & -1333.60 & 1.0 & Wagman et al. $(1968)$ \\
$\mathrm{H}_{2} \mathrm{O}$ & -237.293 & 0.04 & Wagman et al. $(1968)$ \\
$\mathrm{Mg}^{+2}$ & -454.997 & 0.2 & Wagman et al. $(1968)$ \\
$\mathrm{Ni}^{+2}$ & -45.123 & 0.2 & Tardy and Garrels $(1974)$ \\
$\mathrm{SiO}_{2}(\mathrm{aq})$ & -833.70 & 0.5 & Phillips et al. $(1988)$ \\
\end{tabular}

were taken from dissolution experiments (Stoessell, 1988). The constants for the Ni end-members (népouite, pimelite, and falcondoite) were derived from $\Delta G_{\mathrm{f}}$ values calculated by the method proposed by Nriagu (1975), $(\log \mathrm{K} 2, \log \mathrm{K} 4$, and $\log \mathrm{K} 6) . \mathrm{Log} \mathrm{K}$ values predicted by this model are in good agreement with available experimental data on $\mathrm{Mg}$ phases, encouraging the extension of the method to inaccessible phases such as pure Ni phyllosilicate end-members. The error estimated, $<1$ unit in $\log \mathrm{K}$, does not impede the evaluation of the relative stabilities of these phases.

\section{Two-phase equilibria (one solid solution and one aqueous solution)}

The simplest situation is when only one $\mathrm{Mg}-\mathrm{Ni}$ phyllosilicate solid solution precipitates from an aqueous solution. Equilibria between one solid solution and the aqueous solution were plotted in a Lippmann phase diagram (Lippmann, 1980; Glynn and Reardon, 1990; Prieto, 2009). In these diagrams, the aqueous solution in equilibrium with two (or more) end-member components of a solid solution is described by the "total solubility product" $\Sigma \Pi$ eq, (or $\log \Sigma \Pi$ eq), represented on the ordinate, whereas on the abscissa two different variables are depicted: the mole fraction in the solid solution (represented here by $X_{\mathrm{Mg}}$ ) and the activity fraction in the aqueous solution, $X_{\mathrm{Mg}^{2+}}$. $\Sigma \Pi$ eq as a function of $X_{\mathrm{Mg}}$ and $X_{\mathrm{Mg}^{2+}}$ defines the 'solidus' and the 'solutus' curves, respectively. In equilibrium, every $\Sigma \Pi$ eq corresponds to an $X_{\mathrm{Mg}}$ value and an $X_{\mathrm{Mg}^{2+}}$ value (both connected by a horizontal tie-line). An exception is made for pure endmembers or alyotropic points where the two values coincide, or when a miscibility gap exists in the solid solution. In general, the variable $\Sigma \Pi$ defines a state of supersaturation, equilibrium, or undersaturation. When $\Sigma \Pi$ lies above the solutus curve, the solution is supersaturated with respect to a series of solid compositions; below the solutus, the solution is undersaturated with respect to all possible compositions of the solid solution.

On the same diagrams, 'minimum stoichiometric saturation curves', MSS, can be depicted. These curves are useful for illustrating the relations between the composition of a given solid solution and the $\Sigma \Pi$ values of the solution when a congruent dissolution occurs. For mineral solid solutions with low solubility, dissolution that occurs congruently is expected, whereas precipitation is likely to occur in equilibrium or under supersaturation conditions. As discussed below, Lippmann diagrams can help to portray the supergene enrichment of $\mathrm{Ni}$ in phyllosilicates.

Lippmann diagrams (Figure 2a, 2b, 2c) for $\mathrm{Mg}-\mathrm{Ni}$ solid solution in serpentine, kerolite, and sepiolite were calculated on the basis of the $\log \mathrm{K}$ values given above and assuming ideal solid solutions. Note that these curves were calculated for the reduced formula unit of the minerals involved, so that only one octahedral atom enters the formula unit. This amounts to dividing the conventional formulae corresponding to serpentinenépouite and kerolite-pimelite solid solutions by three and dividing those corresponding to the sepiolitefalcondoite series by eight. Log $\mathrm{K}$ values for the dissolution reactions were also divided by the corresponding factors. The main reason for using reduced formulae was that the authors applied a 'mixing on sites' model to solid solutions rather than a molecular mixing model. With the reduced formulae, the equilibrium constants for the dissolution reactions and ionic activity product (IAP) for solutions are simpler and the exponents on the activities of substituting ions are unnecessary. The mole fractions in the solid, $X_{\mathrm{Mg}}$, and the activity fractions in solution, $X_{\mathrm{Mg}^{2+}}$, represented on the abscissa are given by:

$$
\begin{aligned}
X_{\mathrm{Mg}} & =\frac{N_{\mathrm{Mg}}}{N_{\mathrm{Mg}}+N_{\mathrm{Ni}}} \\
X_{\mathrm{Mg}^{2+}} & =\frac{a_{\mathrm{Mg}^{2+}}}{a_{\mathrm{Mg}^{2+}}+a_{\mathrm{Ni}^{2+}}}
\end{aligned}
$$

where $N_{\mathrm{Mg}}$ and $N_{\mathrm{Ni}}$ represent moles of $\mathrm{Mg}$ and $\mathrm{Ni}$ in the solid, and $a_{\mathrm{Mg}^{2+}}$ and $a_{\mathrm{Ni}^{2+}}$ are the activities of $\mathrm{Mg}^{2+}$ and $\mathrm{Ni}^{2+}$, respectively, in solution.

The large contrast between the $\log \mathrm{K}$ values corresponding to end-members of the solutions is reflected in the 'rectangular' rather than 'narrow loop' 
a)

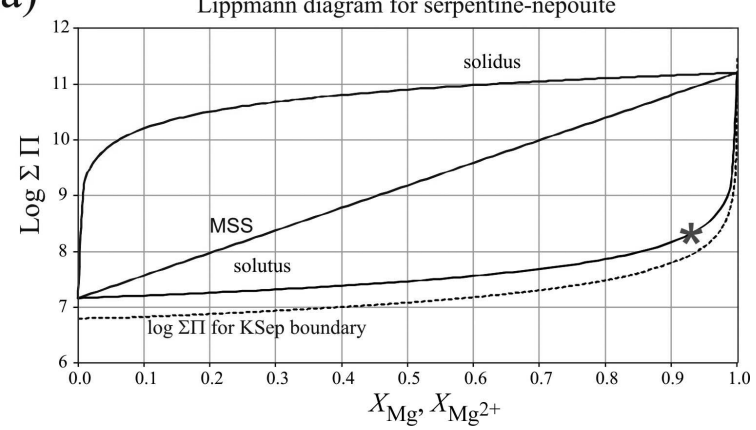

b)

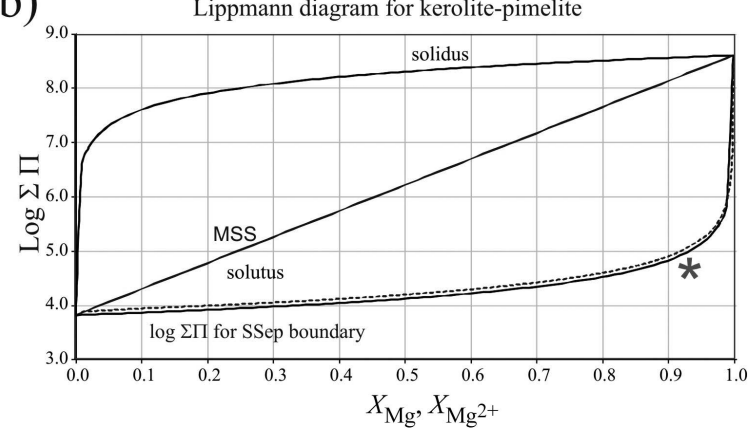

c)

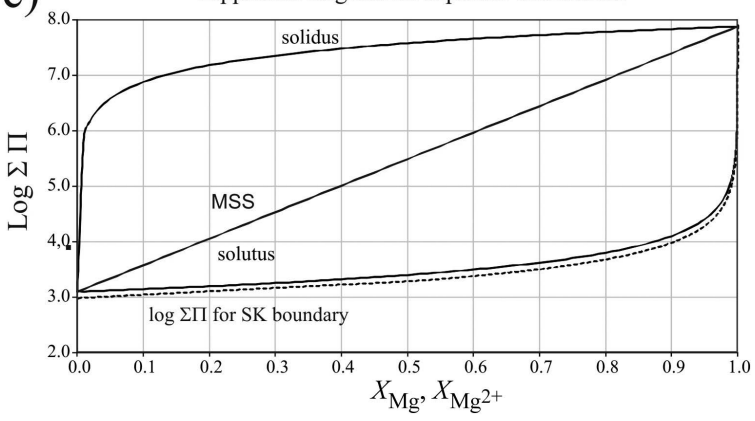

Figure 2. Lippmann diagrams for solid solutions: (a) serpentinenépouite, (b) kerolite-pimelite, and (c) sepiolite-falcondoite. Diagrams show solidus, minimum stoichiometric saturation (MSS), and solutus curves (continuous lines). Dotted curves give the $\log \Sigma \Pi$ values corresponding to the two-solid solution boundaries (see text and Figure 6). Asterisks in Figure $2 \mathrm{a}$ and $2 \mathrm{~b}$ are translations of point $(-5.5,12)$ in Figure 3 into Lippmann's diagram for serpentine-népouite and kerolite-pimelite.

aspect to the solidus and solutus curves (Figure 2a, 2b, 2c). The contrast also explains the efficiency of the supergene enrichment by the mechanism of congruent dissolution-equilibrium precipitation.

In order to use the calculated Lippmann diagrams in a semi-quantitative approach, the possible initial activity ratios of $\mathrm{Mg}^{2+}$ and $\mathrm{Ni}^{2+}$ in aqueous solution are compared with the resulting mole fractions of these metals in the enriched phases. The following example explains $\mathrm{Ni}$ enrichment using the Lippmann diagram (Figure 2a). The values of the ratios $\mathrm{Ni}^{2+} /\left(\mathrm{Mg}^{2+}+\mathrm{Ni}^{2+}\right)$ in solution from congruent dissolution of primary serpentine ranges between $10^{-3}$ and $10^{-5}$ or less. The corresponding tie lines between the solutus and the solidus give the composition of the enriched precipitating solid solution with compositions in the range $\mathrm{Mg}_{0.4-2.4} \mathrm{Ni}_{2.6-0.6} \mathrm{Si}_{2} \mathrm{O}_{5}(\mathrm{OH})_{4}$, which reflects much more $\mathrm{Ni}$ enrichment compared to the primary serpentine. These compositions are reasonable and representative of the amount of $\mathrm{Ni}$ incorporated into a neoformed phase in a single step of the dissolution-precipitation cycle. The repetition of several cycles of congruent dissolutionequilibrium precipitation depends on the hydrological regime in the soil (i.e. alternating dry and wet periods, fluctuations in the level of water table, etc.), and would produce more and more enriched phases. From one cycle to the next, the enriched precipitating phase type may change depending on the variation in silica activity that will determine the enriched precipitating phase type. For example, if the dissolving phase is a $\mathrm{Ni}$-serpentine and the silica activity increases, the next precipitating phase may be a Ni-kerolite and so on.

The factors included in the calculation of $\log \Sigma \Pi$ eq were $\log \left(a_{\mathrm{SiO}_{2}(\mathrm{aq})}\right)$ and $\log \left(\left(a_{\mathrm{Mg}^{2+}}+a_{\mathrm{Ni}^{2+}}\right) /\left(a_{\mathrm{H}^{+}}\right)^{2}\right)$, so that:

$$
\begin{aligned}
& \log \Sigma \Pi_{\text {serpentine }}=\log \left(\left(a_{\mathrm{Mg}^{2+}}+a_{\mathrm{Ni}^{2+}}\right) /\left(a_{\mathrm{H}^{+}}\right)^{2}\right)+ \\
& (2 / 3) \cdot \log \left(a_{\mathrm{SiO}_{2}(\mathrm{aq})}\right) \\
& \log \Sigma \Pi_{\text {kerolite }}=\log \left(\left(a_{\mathrm{Mg}^{2+}}+a_{\mathrm{Ni}^{2+}}\right) /\left(a_{\mathrm{H}^{+}}\right)^{2}\right)+ \\
& (4 / 3) \cdot \log \left(a_{\mathrm{SiO}_{2}(\mathrm{aq})}\right) \\
& \log \Sigma \Pi_{\text {sepiolite }}=\log \left(\left(a_{\mathrm{Mg}^{2+}}+a_{\mathrm{Ni}^{2+}}\right) /\left(a_{\mathrm{H}^{+}}\right)^{2}\right)+ \\
& (3 / 2) \cdot \log \left(a_{\mathrm{SiO}_{2}(\mathrm{aq})}\right)
\end{aligned}
$$

A given solution characterized by $a_{\mathrm{Mg}^{2+}}, a_{\mathrm{Ni}^{2+}}, a_{\mathrm{H}^{+}}$, and $a_{\mathrm{SiO}_{2} \text { (aq) }}$ is represented by a point in the plane of the variables $\log \left(a_{\mathrm{SiO}_{2}(\mathrm{aq})}\right)$ and $\log \left(\left(a_{\mathrm{Mg}^{2+}}+a_{\mathrm{Ni}^{2+}}\right) /\left(a_{\mathrm{H}^{+}}\right)^{2}\right)$. The equilibrium equation for each solid solution is represented in such a diagram by straight lines with equations.

For serpentine-népouite:

$$
\begin{aligned}
\log \left(X_{\mathrm{Mg}} \cdot \mathrm{K}_{1}+\left(1-X_{\mathrm{Mg}}\right) \cdot \mathrm{K}_{2}\right)= \\
\log \left(\frac{a_{\mathrm{Mg}^{2+}}+a_{\mathrm{Ni}^{2+}}}{\left(a_{\mathrm{H}^{+}}\right)^{2}}\right)+\frac{2}{3} \cdot \log \left(a_{\mathrm{SiO}_{2} \mathrm{aq}}\right)
\end{aligned}
$$

For kerolite-pimelite:

$$
\begin{aligned}
\log \left(X_{\mathrm{Mg}} \cdot \mathrm{K}_{3}+\left(1-X_{\mathrm{Mg}}\right) \cdot \mathrm{K}_{4}\right)= \\
\log \left(\frac{a_{\mathrm{Mg}^{2+}}+a_{\mathrm{Ni}^{2+}}}{\left(a_{\mathrm{H}^{+}}\right)^{2}}\right)+\frac{4}{3} \cdot \log \left(a_{\mathrm{SiO}_{2} \mathrm{aq}}\right)
\end{aligned}
$$

For sepiolite-falcondoite:

$$
\begin{aligned}
& \log \left(X_{\mathrm{Mg}} \cdot \mathrm{K}_{5}+\left(1-X_{\mathrm{Mg}}\right) \cdot \mathrm{K}_{6}\right)= \\
& \log \left(\frac{a_{\mathrm{Mg}^{2+}}+a_{\mathrm{Ni}^{2+}}}{\left(a_{\mathrm{H}^{+}}\right)^{2}}\right)+\frac{3}{2} \cdot \log \left(a_{\mathrm{SiO}_{2} \mathrm{aq}}\right)
\end{aligned}
$$

where $X_{\mathrm{Mg}}$ and $\left(1-X_{\mathrm{Mg}}\right)$ are the mole-fractions of $\mathrm{Mg}$ and $\mathrm{Ni}$ in the solids. Note that $\mathrm{K}_{1}, \mathrm{~K}_{2}, \ldots \mathrm{K}_{6}$ represent the equilibrium constants for the reduced formulae of the end-members, as indicated above. 


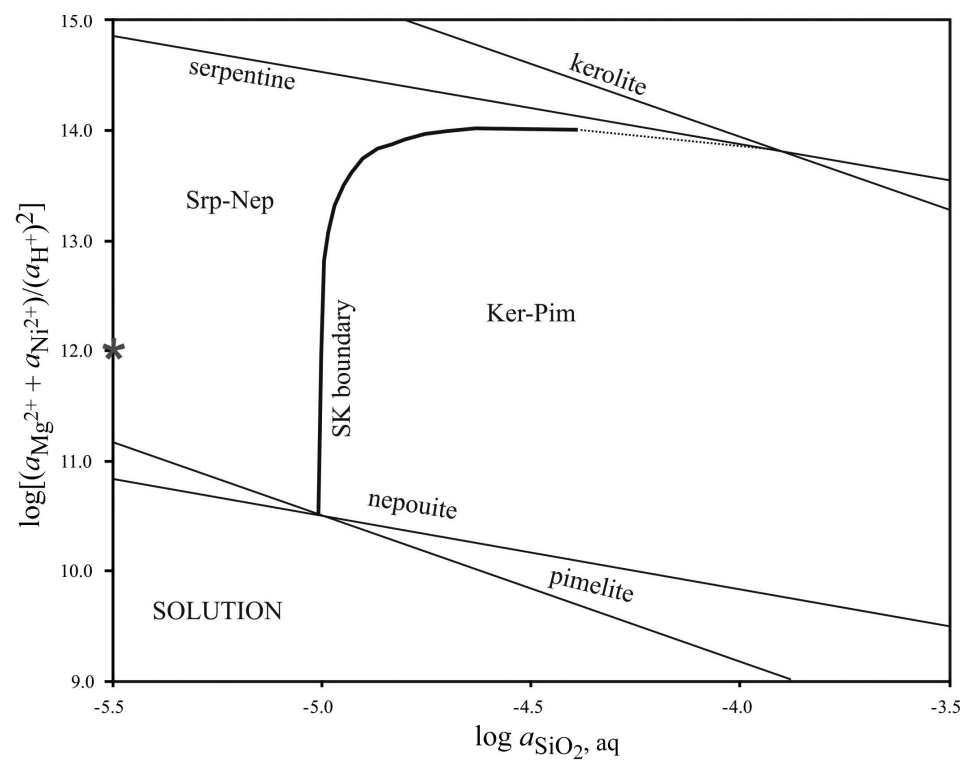

Figure 3. Path followed by the equilibrium between Srp-Nep and Ker-Pim, plotted in the space of $\log a_{\mathrm{SiO}_{2}(\mathrm{aq})}-\log \left(\left(a_{\mathrm{Mg}^{2}+}+a_{\mathrm{Ni}^{2+}}\right) /\right.$ $\left.\left(a_{\mathrm{H}^{+}}\right)^{2}\right)$. A section of the SK curve is metastable (dashed line). The asterisk on coordinates $(-5.5,12)$ is translated to Lippmann's diagrams in Figure 2a, $2 \mathrm{~b}$.

For every point in this diagram, three straight lines cross, corresponding to three possible solid solutions in equilibrium with the solution. However, apart from the boundaries between different phases, only one solid is in equilibrium with the aqueous solution, the other two candidates being undersaturated. Each solid solution (Srp-Nep, Ker-Pim, or Sep-Fal) is defined by a field in the (predominance area) activity diagram $\left[\log \left(a_{\mathrm{SiO}_{2}(\mathrm{aq})}\right), \log \left(\left(a_{\mathrm{Mg}^{2+}}+a_{\mathrm{Ni}^{2+}}\right) /\left(a_{\mathrm{H}^{+}}\right)^{2}\right)\right]($ see, for instance, Figure 3).
Three-phase equilibria (two solid-solutions and one aqueous solution)

Several authors have described garnierites as an intimate intermixing of two or more Ni-containing phases. The most common association encountered was serpentine-kerolite solid solutions (Vitovskaya et al., 1969; Brindley and Hang, 1973; Wells et al., 2009), but other associations such as chlorite-kerolite, with or without quartz, and a sample composed of sepiolite

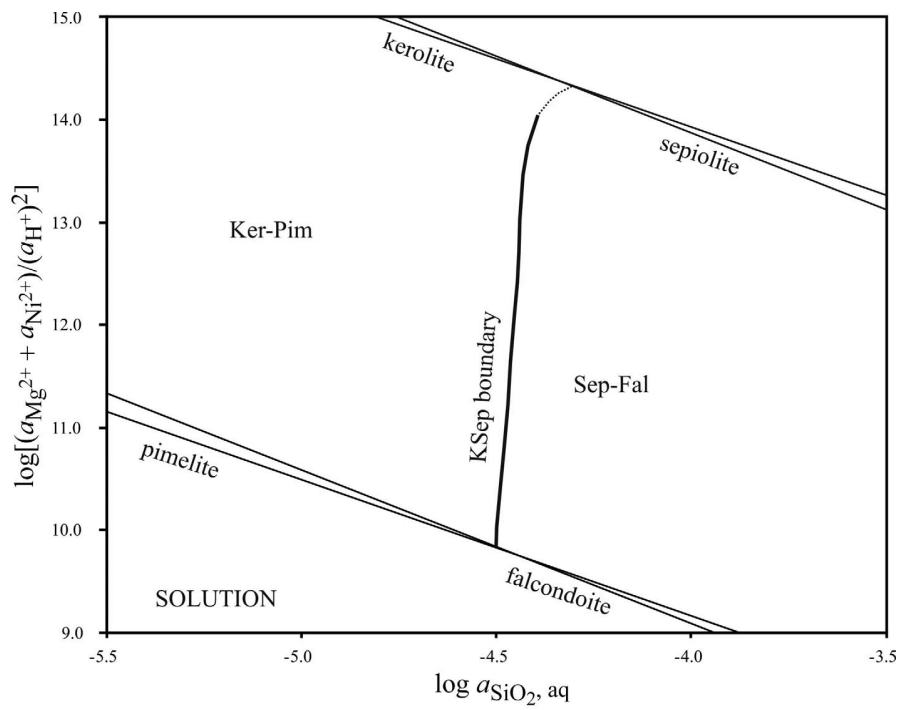

Figure 4. Path followed by the equilibrium between Ker-Pim and Sep-Fal, plotted in the space of $\log a_{\mathrm{SiO}_{2}(\mathrm{aq})}-\log \left(\left(a_{\mathrm{Mg}^{2}}+a_{\mathrm{Ni}^{2}+}\right) /\right.$ $\left.\left(a_{\mathrm{H}^{+}}\right)^{2}\right)$. A section of the KSep curve is metastable (dashed line). 
plus minor serpentine and talc were described by Springer (1974). At a micrometric scale, all these combinations of mineral Ni-bearing phases in Caribbean Ni-laterites have been observed by the present authors. However, not all mixed particulate masses of garnierite are the result of an equilibrium precipitation, so it is important to distinguish the associations that occur as a result of mechanical mixing in breccias or accumulations in fractures, from those that are the result of co-precipitation at near-equilibrium conditions.

\section{Simultaneous precipitation of serpentine-népouite and} kerolite-pimelite solid solutions from aqueous solution

When serpentine-népouite and kerolite-pimelite solid solutions precipitate from an aqueous solution in equilibrium, the equilibrium reactions $1,2,3$, and 4 (Table 2) can be combined to give the equilibrium between the four end-members of both solid solutions. The reaction sought is:

$$
\begin{aligned}
& \mathrm{MgSi}_{2 / 3} \mathrm{O}_{5 / 3}(\mathrm{OH})_{4 / 3}+\mathrm{NiSi}_{4 / 3} \mathrm{O}_{10 / 3}(\mathrm{OH})_{2 / 3}= \\
& \mathrm{NiSi}_{2 / 3} \mathrm{O}_{5 / 3}(\mathrm{OH})_{4 / 3}+\mathrm{MgSi}_{4 / 3} \mathrm{O}_{10 / 3}(\mathrm{OH})_{2 / 3}
\end{aligned}
$$

and its equilibrium constant is:

$\log \mathrm{K}_{\mathrm{SK}}=(1 / 3) \cdot(\log \mathrm{K} 1-\log \mathrm{K} 2-\log \mathrm{K} 3+\log \mathrm{K} 4)=$ $-0.73 \pm 0.32$

The path of the solution in equilibrium with the two solid solutions is a curve (SK) that connects the intercept of serpentine-kerolite with that of népouite-pimelite (Figure 3). One section of this curve presents a metastable extension (dashed line, Figure 3). The coordinates of this curve permit the calculation of the total solubility product $(\Sigma \Pi)$ of different minerals in the system $\mathrm{MgO}-\mathrm{NiO}-\mathrm{SiO}_{2}-\mathrm{H}_{2} \mathrm{O}$, and this helps in the characterization of the solutions, in combination with the
Lippmann diagrams. For example, the $\log \Sigma \Pi$ values corresponding to sepiolite-falcondoite solid solution (equation 4) were plotted on the Lippmann diagram (Figure 2c). All the terms of the Sep-Fal s.s. are undersaturated for all equilibria Srp-Nep+Ker-Pim solid solutions, with the exception of the end near the serpentine-kerolite intercept (Figure 5).

An example of the use of the activity diagram (Figure 3), combined with Lippmann diagrams (Figures $2 \mathrm{a}$ and $2 \mathrm{~b}$ ), is as follows. Points falling to the left of the SK curve characterize solutions that will precipitate Srp-Nep s.s. For every point in this field, the $\log \Sigma \Pi$ value for Srp-Nep and Ker+Pim can be calculated using equations 2 and 3 . For a given value of $\log \Sigma \Pi_{\text {serpentine, }}$, the corresponding value of $a_{\mathrm{Mg}^{2+}} /\left(a_{\mathrm{Mg}^{2+}}\right.$ $\left.+a_{\mathrm{Ni}^{2}+}\right)$ is given by the solutus in the corresponding Lippmann diagram. The same activity ratio applied to the Lippmann diagram for kerolite will plot under the solutus, indicating that kerolite s.s. composition is undersaturated. For example, for a point with coordinates $(-5.5,12)$ (Figure 3$)$, a Srp-Nep crystal is in equilibrium with a solution with an activity ratio $a_{\mathrm{Mg}^{2}} /\left(a_{\mathrm{Mg}^{2+}}+a_{\mathrm{Ni}^{2+}}\right)$ of 0.93 . The corresponding point in the Lippmann diagram of Ker-Pim s.s. has coordinates $(0.93,4.66)$, falling under the solutus curve, and then Ker-Pim s.s. would be undersaturated.

Alternatively, the same statement can be inversely formulated: for given values of $\log \Sigma \Pi$ and $a_{\mathrm{Mg}^{2+}} /\left(a_{\mathrm{Mg}^{2+}}\right.$ $\left.+a_{\mathrm{Ni}^{2}+}\right)$, corresponding to an equilibrium Ker-Pim s.s. with solution, a series of (Srp-Nep) s.s. exists and they are supersaturated. This can be demonstrated graphically using the Lippmann diagrams (Figure 2a, 2b).

Similarly, points in the diagram to the right of the SK curve characterize the conditions for equilibrium precipitation of a Ker-Pim s.s.

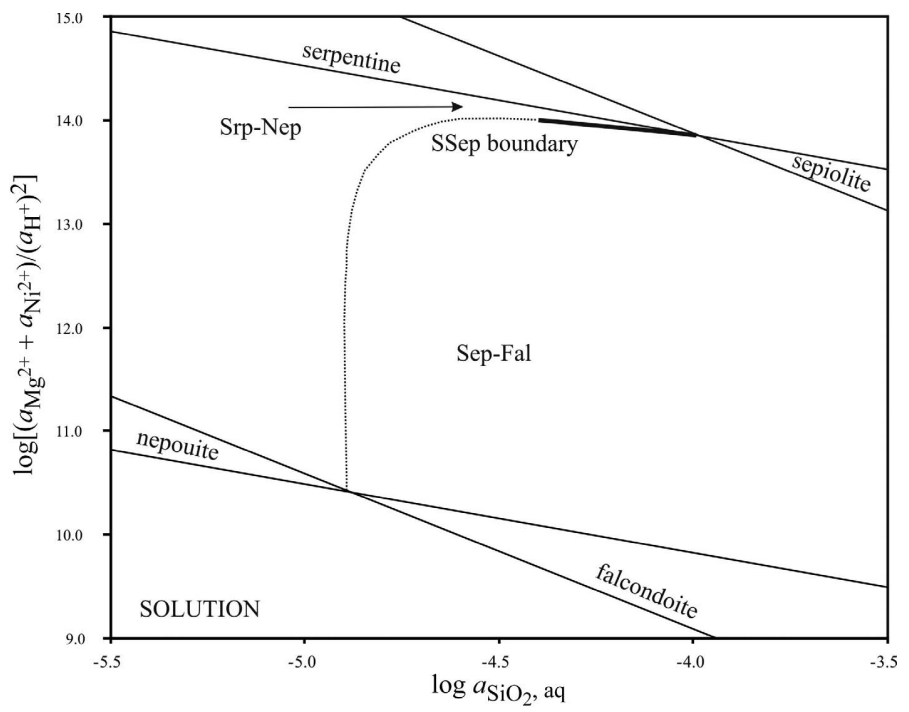

Figure 5. Path followed by the equilibrium between Srp-Nep and Sep-Fal, plotted in the space of $\log a_{\mathrm{SiO}_{2}(\mathrm{aq})}-\log \left(\left(a_{\mathrm{Mg}^{2+}}+a_{\mathrm{Ni}^{2}+}\right) /\right.$ $\left.\left(a_{\mathrm{H}^{+}}\right)^{2}\right)$. A section of the SSep curve is metastable (dashed line). 
Simultaneous precipitation of kerolite-pimelite and sepiolite-falcondoite solid solutions from aqueous solution

The equilibrium involved is:

$$
\begin{aligned}
& \mathrm{MgSi}_{4 / 3} \mathrm{O}_{10 / 3}(\mathrm{OH})_{2 / 3} 1 / 3 \mathrm{H}_{2} \mathrm{O}+ \\
& \mathrm{NiSi}_{3 / 2} \mathrm{O}_{15 / 4}(\mathrm{OH})_{1 / 2}\left(\mathrm{H}_{2} \mathrm{O}\right)_{1 / 2} \cdot \mathrm{H}_{2} \mathrm{O}= \\
& \mathrm{NiSi}_{4 / 3} \mathrm{O}_{10 / 3}(\mathrm{OH})_{2 / 3} 1 / 3 \mathrm{H}_{2} \mathrm{O}+ \\
& \mathrm{MgSi}_{3 / 2} \mathrm{O}_{15 / 4}(\mathrm{OH})_{1 / 2}\left(\mathrm{H}_{2} \mathrm{O}\right)_{1 / 2} \cdot \mathrm{H}_{2} \mathrm{O}\left(\log \mathrm{K}_{\mathrm{KSep}}\right)
\end{aligned}
$$

and its equilibrium constant is:

$\log \mathrm{K}_{\mathrm{KSep}}=(1 / 3) \cdot(\log \mathrm{K} 3-\log \mathrm{K} 4)+$

$(1 / 8) \cdot(+\log \mathrm{K} 6-\log \mathrm{K} 5)=-0.02 \pm 0.46$

Using this equilibrium constant for reaction 9, the equilibrium path for these two solid solutions (curve KSep, Figure 4) was constructed on the same basis as curve SK (Figure 3). This curve separates the stability field of Ker-Pim (left) from that of the Sep-Fal.

Along the equilibrium path of Ker-Pim with Sep-Fal, (curve KSep), Srp-Nep s.s. are undersaturated, except for high activity ratios of $X_{\mathrm{Mg}^{2+}}$ when they become supersaturated (Figure 5). The corresponding $\log \Sigma \Pi$ curve is depicted in Figure 2a.

Simultaneous precipitation of serpentine-népouite and sepiolite-falcondoite solid solutions from aqueous solution

Equilibrium between these solid solutions is given by the reaction:

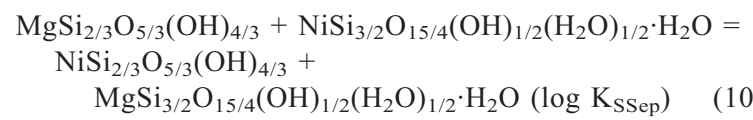

The equilibrium constant of this reaction was obtained by proper combinations of the reactions 1 $2-5+6$ (Table 2), as in the previous examples, yielding $\log \mathrm{K}_{\mathrm{SSep}}=-0.76 \pm 0.42$. The equilibrium path of the equilibrium Srp-Nep+Sep-Fal in the activity diagram is shown in Figure 5. Intimate mixing of these two solid solutions have not been observed. This is consistent with the fact that the curve for Srp-Nep+SepFal equilibrium is metastable, except for the end near the intercept of serpentine-sepiolite (Figure 5). The metastable extension falls in the field of Ker-Pim s.s.: the calculated $\log \Sigma \Pi$ for Ker-Pim, translated to the Lippmann diagram lies above the solutus up to an activity ratio $X_{\mathrm{Mg}^{2+}}$ near 0.98 (Figure $2 \mathrm{~b}$ ).

\section{Simultaneous precipitation of Ni-bearing sepiolite and quartz}

One of the most commonly observed associations in garnierites is the solid solution Sep-Fal with quartz. The equilibrium path in this case is merely the vertical straight line $\log \left(a_{\mathrm{SiO}_{2} \mathrm{aq}}\right)=-4.0$ corresponding to the solubility of quartz. For greater activities of silica, SepFal s.s. may be associated with amorphous silica.

Whether two solid solutions plus quartz can coexist in equilibrium with an aqueous solution is uncertain. The quartz boundary, represented by a vertical straight line at $\log \left(a_{\mathrm{SiO}_{2}}\right)=-4$, intercepts the curve SSep and the metastable extension of $\mathrm{KS}$, in the Mg-rich end of these curves (Figure 6). Two solid solutions plus quartz might precipitate in near-equilibrium conditions. The position of the intersections of pure phase boundaries in the activity diagram and especially their intersections could

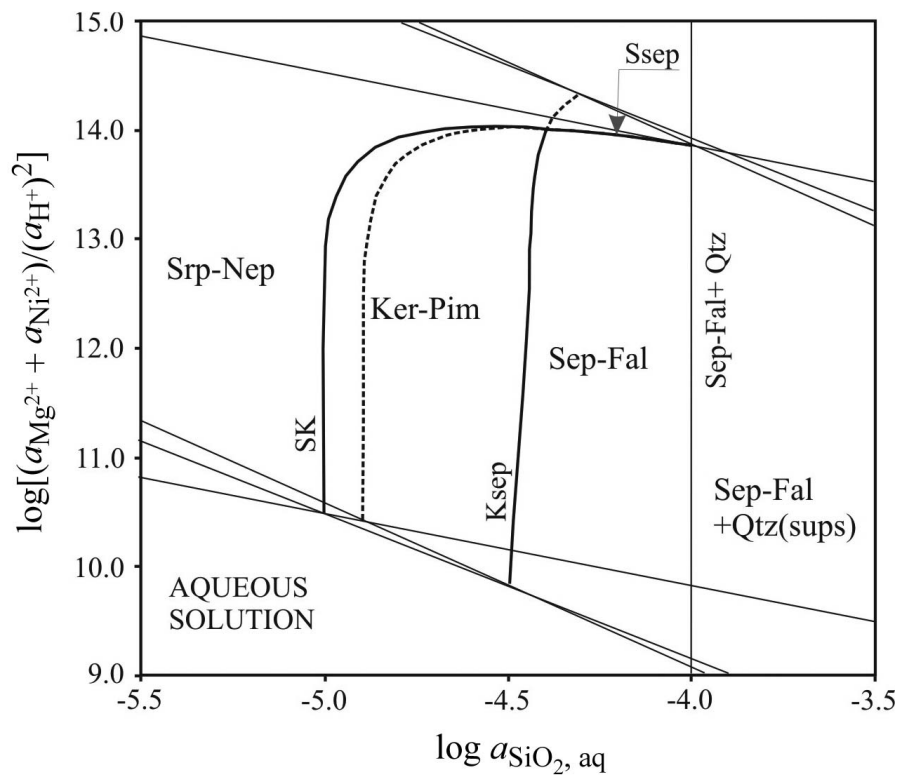

Figure 6. Fields corresponding to the three solid solutions and boundaries: Srp-Nep+Ker-Pim; Ker-Pim+Sep-Fal and Srp-Nep+SepFal. Dashed lines are metastable extensions of these equilibria. Vertical line at $\log \left(a_{\mathrm{SiO}_{2}(\mathrm{aq})}\right)=-4$ gives equilibrium between quartz+Sep-Fal. 
change considerably due to uncertainties in the $\log \mathrm{K}$ values, however.

\section{MATERIALS AND METHODS}

For the present study, garnierite samples from the Falcondo (Dominican Republic) and Loma de Níquel (Venezuela) Ni-laterite deposits were selected. The same samples were studied by Proenza et al. (2008), Tauler et al. (2009), Soler et al. (2010), and Villanova-de-Benavent et al. (2011a, 2011b). In addition, a list of garnierite minerals from $\mathrm{Ni}$ laterites worldwide was compiled in which accurate quantitative electron microprobe data are available (see Figure 1). Garnierites typically precipitate with strong compositional zoning, sometimes with oscillatory content in $\mathrm{Ni}$, and with transitions from one structural type to another (e.g. from $\mathrm{Ni}$-serpentine to Ni-kerolite). Thin veinlets of quartz cross the garnierite structures (Tauler et al., 2009; Villanova-deBenavent et al., 2011b). As both the Lippmann and the activity diagrams were built on the basis of partially theoretically derived equilibrium constants ( $\log \mathrm{K}$ values for $\mathrm{Ni}$ end-members), having some experimental control over the reliability of the equilibrium constants used in the graphical representations was considered to be necessary. For this purpose, $\sim 100$ polished sections of the material described above were examined to find garnierites consisting of two well characterized phases suitable for detailed chemical analyses, avoiding areas with pronounced zonation and oscillatory composition.

\section{Determination of $\log K_{S K}$ from biphasic particulate masses of serpentine-nepouite and kerolite-pimelite solid solutions}

A garnierite sample from the Falcondo Mine was a clear example of different generations of co-precipitated Ni-enriched serpentine plus kerolite (Figure 7a). The garnierites consist of homogeneous light green masses cut in places by thin veinlets of quartz $(1 \mathrm{~mm}$ thick or less) filling fractures or cavities in the saprolite horizon that appeared to have formed under near equilibrium conditions. Under the optical microscope, only quartz veinlets were distinguished from a homogeneous, poorly crystalline yellowish-green mass. Serpentine (mainly lizardite) and talc, in the form of the fine-grained hydrated variety known as kerolite (Brindley et al., 1977), was clearly distinguished by powder X-ray diffraction (XRD). The proportion of phases and the mean size of crystallites were estimated by Rietveld analysis of the XRD profile (Figure 8). Electron microprobe analyses of areas $1-2 \mu \mathrm{m}$ in size revealed fractions of kerolite together with fractions of serpentine. The TEM studies also showed that the mineral particles were nm-sized (Soler et al., 2008; Villanovade-Benavent et al., 2011a).
A statistically sufficient number of points analyzed by EMP, in principle, allows the determination as to whether the precipitation of the mixture was produced under equilibrium conditions as well as the composition

a)
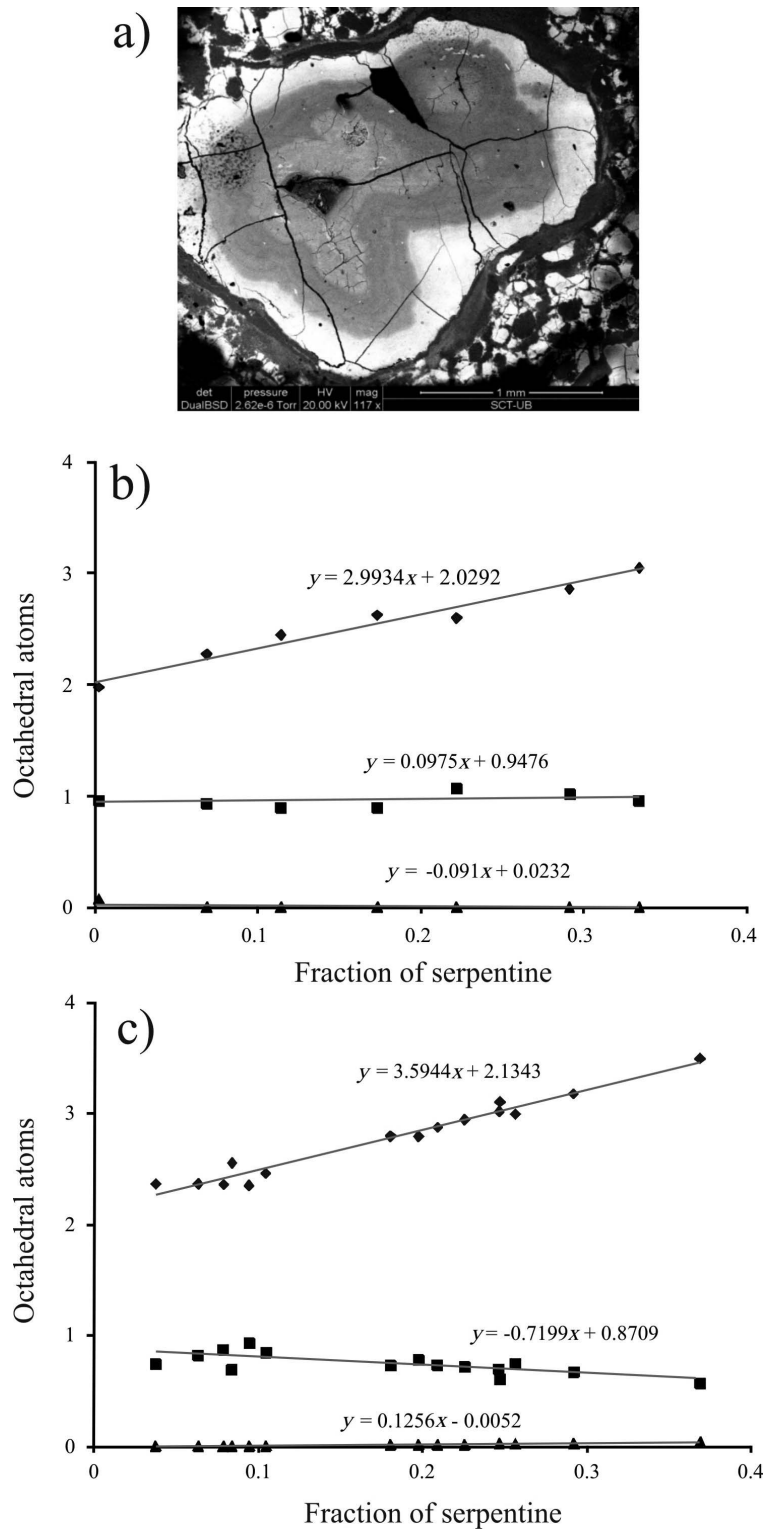

Figure 7. (a) Different generations of kerolite and serpentine with different Ni contents (backscattered electrons). Sample DR1 from Falcondo Mine, Dominican Republic. The analysis given in Table 5 and plotted in Figure $7 \mathrm{~b}$ corresponds to the inner gray band. (b) Plot of the EMP analyses in the central area of Figure $7 \mathrm{a}$, which consisted of an intermixing of $\operatorname{Srp}_{84}-\mathrm{Nep}_{17}$ and $\mathrm{Ker}_{68}-\mathrm{Pim}_{32}$. Values are octahedral atoms per formula unit (a.p.f.u.) on the basis of four Si. Diamonds: Mg, squares: $\mathrm{Ni}$, triangles: $\mathrm{Fe}^{2+}$. (c) Plot of the EMP analyses of a sample from Loma de Hierro Mine (Venezuela) which consisted of an intermixing of $\mathrm{Srp}_{95}-\mathrm{Nep}_{3}$ and $\mathrm{Ker}_{71}-\mathrm{Pim}_{29}$. Values are octahedral a.p.f.u. on the basis of four Si. Diamonds: Mg, squares: Ni, triangles: $\mathrm{Fe}^{2+}$. 


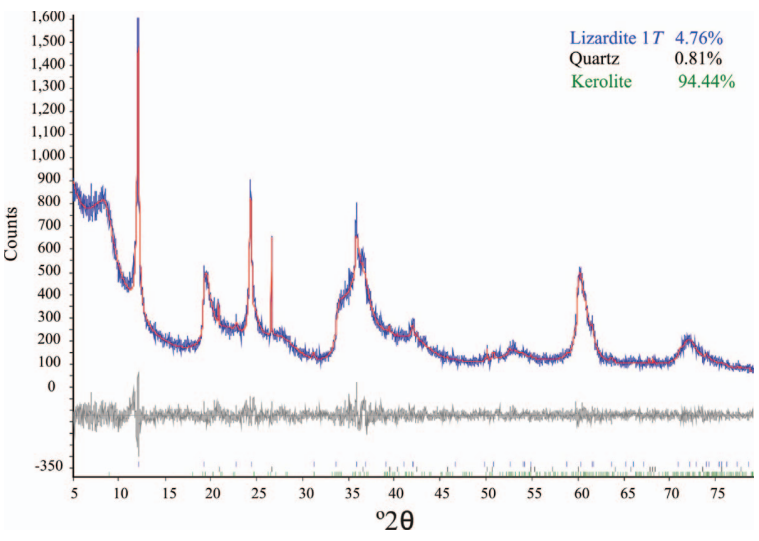

Figure 8. Powder XRD pattern of a garnierite sample DR1 (Falcondo Mine, Dominican Republic), which consisted of coprecipitated serpentine $(4.76 \%)$, kerolite $(94.44 \%)$, and $0.81 \%$ quartz precipitated in veinlets. The measured profile is represented by the continuous line (Rietveld method); the lower trace represents the difference between measured and calculated profiles; small vertical bars indicate the positions of Bragg reflections.

and the amount of each phase. The composition of each phase gives the distribution of $\mathrm{Ni}$ and $\mathrm{Mg}$ between them, and the equilibrium constant for the reaction 8 . The area illuminated by the electron probe beam includes many particles of both phases in a nm-scale intermixing of serpentine and kerolite s.s. The fraction of each phase can be obtained by adding the atomic coefficient of octahedral atoms, expressing the formula units of both phases on a common number of four $\mathrm{Si}$ :

Serpentine s.s.: $(\mathrm{Mg}, \mathrm{Ni})_{6} \mathrm{Si}_{4} \mathrm{O}_{10}(\mathrm{OH})_{8}$

Kerolite s.s.: $\left(\mathrm{Mg}, \mathrm{Ni}_{3}\right)_{3} \mathrm{Si}_{4} \mathrm{O}_{10}(\mathrm{OH})_{2} \cdot \mathrm{H}_{2} \mathrm{O}$

The fraction of serpentine ( $\left.X_{\text {serpentine }}\right)$ probed was ( $\Sigma$ octahedral atoms -3 )/3. If simultaneous precipitation of both phases proceeds in equilibrium, all particles of the same phase should have the same composition. For each point analyzed, a given increase in the serpentine fraction represents a constant increase in each octahedral cation $\left(\mathrm{Mg}, \mathrm{Ni}, \mathrm{Fe}^{2+}\right)$. Plotting these atomic contents against the serpentine fraction yielded straight lines for $\mathrm{Mg}, \mathrm{Ni}$, and $\mathrm{Fe}^{2+}$ and the intercepts at $X_{\text {serpentine }}=0$ and $X_{\text {serpentine }}=1$ gave the compositions of (Ker-Pim) s.s. and (Srp-Nep) s.s. in the sample analyzed (Table 5). The reverse was also true: if the atomic contents of substitutable cations failed to lie on straight lines, the probed sample was inhomogeneous and consisted of particles of different compositions.

The $\log \mathrm{K}_{\mathrm{SK}}$ 'analytical' value can be obtained from the composition of the equilibrium phases. For instance, the supposed ideal solid solutions in sample DR1 (Falcondo Mine) (Figure 7b) gave $\log \mathrm{K}_{\mathrm{SK}}=-0.35$, (with $\left.\sigma\left(\log \mathrm{K}_{\mathrm{SK}}\right)= \pm 0.08\right)$ whereas that obtained from the analyses of the sample from Loma de Hierro Mine (Venezuela) (Figure 7c) gave $\log \mathrm{K}_{\mathrm{SK}}=-1.19$ (with $\left.\sigma\left(\log \mathrm{K}_{\mathrm{SK}}\right)= \pm 0.55\right)$. This discrepancy provides a crude approach to the errors involved in the analytical estimation of $\log \mathrm{K}_{\mathrm{SK}}$. Nevertheless, both 'analytical equilibrium constants' for reaction 8 indicated that $\mathrm{Ni}$ atoms are better accommodated in the kerolite structure. These values fall around the value derived theoretically for $\log \mathrm{K}_{\mathrm{SK}}(-0.73)$.

\section{Determination of $\log K_{K S e p}$ from biphasic particulate masses of kerolite-pimelite and sepiolite-falcondoite solid solutions}

The same method was applied to estimate $\log \mathrm{K}_{\mathrm{KSep}}$. In this case, an homogeneous mass of greenish Ni-bearing minerals from Falcondo Mine were characterized unambiguously as a fine mixture of sepiolitefalcondoite and kerolite-pimelite solid solutions using powder X-ray micro-diffraction on an area of $500 \mu \mathrm{m}$ (Figure 9) and EMP analyses (Table 6). Diffraction was obtained using a Bruker D8 microdiffraction instrument equipped with a general area detector system (GADDS). As for the Ni-bearing serpentine and kerolite garnierites, the fraction of each phase in each individual analysis (the area illuminated by the electron beam) was obtained readily, expressing the unit formulae on a common basis (the same number of silicon atoms):

$$
\begin{aligned}
& \text { Kerolite s.s.: }(\mathrm{Mg}, \mathrm{Ni})_{9} \mathrm{Si}_{12} \mathrm{O}_{30}(\mathrm{OH})_{6} \cdot 3 \mathrm{H}_{2} \mathrm{O} \\
& \text { Sepiolite s.s.: }(\mathrm{Mg}, \mathrm{Ni})_{8} \mathrm{Si}_{12} \mathrm{O}_{30}(\mathrm{OH})_{4}\left(\mathrm{H}_{2} \mathrm{O}\right)_{4} \cdot 8 \mathrm{H}_{2} \mathrm{O}
\end{aligned}
$$

The fraction of kerolite was then ( ooctahedral cations - 8). The intercepts of the straight lines obtained by plotting $\mathrm{Mg}, \mathrm{Ni}$, and $\mathrm{Fe}^{2+}$ contents against the fraction of kerolite gave the compositions of both solid solutions. From these, an estimated equilibrium constant for the next reaction $\left(\log \mathrm{K}_{\mathrm{KSep}}=-0.16\right)$ was obtained. In contrast to the results for the mixtures of serpentine and kerolite, however, the points plotting $\mathrm{Mg}$ and $\mathrm{Ni}$ against the fraction of kerolite were more dispersed so that the estimation of the equilibrium constant (9) was less reliable. These data show that the sepiolite structure, compared with kerolite, is slightly preferred by $\mathrm{Ni}$.

Analyses of polished sections of garnierites did not reveal biphasic mixtures of serpentine-nepouite and sepiolite-falcondoite solid solutions, so that the equilibrium distribution of $\mathrm{Mg}$ and $\mathrm{Ni}$ between these phases could not be ascertained analytically. This result is consistent with the narrow calculated stable boundary obtained theoretically for these solid solutions, as discussed below.

\section{RESULTS AND DISCUSSION}

By superposing SK, KSep, and SSep boundaries (Figures 3, 4, and 5) a mineral stability diagram for the system $\mathrm{MgO}-\mathrm{NiO}-\mathrm{SiO}_{2}-\mathrm{H}_{2} \mathrm{O}$ was obtained (Figure 6). The six straight lines correspond to the solubilities of the six end-members (Srp, Nep, Ker, Pim, Sep, Fal). Three curves connecting the two intersecting points of pure end-members (curves SK, KSep, and SSep) depict the 
Table 5. Analyses of garnierites plotted in Figure 7b, 7c.

$\begin{array}{lllllllllll}\mathrm{Mg} & \mathrm{Al} & \mathrm{Si} & \mathrm{Ca} & \mathrm{Ti} & \mathrm{Cr} & \mathrm{Mn} & \mathrm{Fe} & \mathrm{Ni} & \mathrm{Mg}+\mathrm{Ni}+\mathrm{Fe} & \text { Serpentine }\end{array}$
fraction

\begin{tabular}{|c|c|c|c|c|c|c|c|c|c|c|c|}
\hline \multicolumn{12}{|l|}{ Falcondo } \\
\hline DR1_1 & 1.9739 & 0.0277 & 4.0000 & 0.0097 & 0.0000 & 0.0007 & 0.0000 & 0.0749 & 0.9588 & 3.0076 & $\begin{array}{l}0.0025 \\
0.4702\end{array}$ \\
\hline DR1_2 & 3.1268 & 0.0229 & 4.0000 & 0.0058 & 0.0008 & 0.0034 & 0.0030 & 0.0407 & 1.2432 & 4.4106 & 0.4702 \\
\hline DR1_3 & 1.8431 & 0.0242 & 4.0000 & 0.0114 & 0.0000 & 0.0019 & 0.0006 & 0.0192 & 1.0512 & 2.9135 & -0.0288 \\
\hline DR1_4 & 3.0484 & 0.0194 & 4.0000 & 0.0039 & 0.0000 & 0.0007 & 0.0000 & 0.0000 & 0.9545 & 4.0028 & 0.3343 \\
\hline DR1_5 5 & 2.1215 & 0.0134 & 4.0000 & 0.0052 & 0.0012 & 0.0006 & 0.0000 & 0.0014 & 0.8765 & 2.9994 & -0.0002 \\
\hline DR1_6 6 & 2.8595 & 0.0149 & 4.0000 & 0.0058 & 0.0000 & 0.0014 & 0.0012 & 0.0000 & 1.0146 & 3.8741 & 0.2914 \\
\hline DR1 7 & 2.4442 & 0.0133 & 4.0000 & 0.0046 & 0.0013 & 0.0014 & 0.0000 & 0.0014 & 0.8973 & 3.3429 & 0.1143 \\
\hline DR1 8 & 2.6257 & 0.0137 & 4.0000 & 0.0044 & 0.0006 & 0.0007 & 0.0000 & 0.0028 & 0.8918 & 3.5202 & 0.1734 \\
\hline DR1-9 & .2732 & 0.0126 & 4.0000 & 0.0062 & 0.0012 & 0.0007 & 0.0011 & 0.0014 & 0.9320 & 3.2066 & 0.068 \\
\hline DR1_-10 & .5991 & 0.0171 & 4.0000 & 0.0036 & 0.0019 & 0.0027 & 0.0000 & 0.0007 & 1.0662 & 3.6660 & 0.2220 \\
\hline \multicolumn{12}{|c|}{ Loma de $\mathrm{H}$} \\
\hline MT_1 & 3602 & 0.0009 & 4.0000 & 0.0000 & 0.0011 & 0.0065 & 0.0000 & 0.0031 & 0.8723 & 3.2357 & 0.078 \\
\hline $\mathrm{MT}^{-} 2$ & 2.3669 & 0.0026 & 4.0000 & 0.0000 & 0.0006 & 0.0035 & 0.0000 & 0.0043 & 0.8184 & 3.1896 & 0.063 \\
\hline MT_3 & 2.4614 & 0.0009 & 4.0000 & 0.0000 & 0.0011 & 0.0042 & 0.0010 & 0.0044 & 0.8469 & 3.3128 & 0.10 \\
\hline $\mathrm{MT}^{-} 4$ & 2.7949 & 0.0055 & 4.0000 & 0.0000 & 0.0006 & 0.0279 & 0.0022 & 0.0170 & 0.7798 & 3.5917 & 0.197 \\
\hline $\mathrm{MT}^{-} 5$ & 2.9445 & 0.0037 & 4.0000 & 0.0000 & 0.0006 & 0.0086 & 0.0022 & 0.0182 & 0.7130 & 3.6758 & 0.2253 \\
\hline MT_6 & 2.9932 & 0.0046 & 4.0000 & 0.0000 & 0.0000 & 0.0049 & 0.0016 & 0.0292 & 0.7460 & 3.7685 & 0.256 \\
\hline MT_7 & 3.0171 & 0.0073 & 4.0000 & 0.0000 & 0.0000 & 0.0105 & 0.0000 & 0.0261 & 0.6959 & 3.7390 & 0.246 \\
\hline MT_8 & .3492 & 0.0000 & 4.0000 & 0.0000 & 0.0000 & 0.0036 & 0.0000 & 0.0063 & 0.9266 & 3.2822 & 0.09 \\
\hline MT 9 & 2.8752 & 0.0009 & 4.0000 & 0.0000 & 0.0000 & 0.0596 & 0.0000 & 0.0184 & 0.7328 & 3.6264 & 0.20 \\
\hline $\mathrm{MT}_{-10}^{-10}$ & 2.7970 & 0.0055 & 4.0000 & 0.0000 & 0.0000 & 0.0355 & 0.0000 & 0.0168 & 0.7266 & 3.5404 & $0.18 c$ \\
\hline $\mathrm{MT}^{-} 11$ & 3.1769 & 0.0075 & 4.0000 & 0.0000 & 0.0006 & 0.0101 & 0.0006 & 0.0286 & 0.6691 & 3.8746 & 0.291 \\
\hline MT_12 & .4957 & 0.0047 & 4.0000 & 0.0000 & 0.0006 & 0.0125 & 0.0027 & 0.0431 & 0.5669 & 4.1057 & 0.368 \\
\hline $\mathrm{MT}^{-} 13$ & 3.1042 & 0.0036 & 4.0000 & 0.0000 & 0.0000 & 0.0225 & 0.0000 & 0.0334 & 0.6030 & 3.7406 & 0.24 \\
\hline $\mathrm{MT}^{-} 14$ & 2.5535 & 0.0052 & 4.0000 & 0.0000 & 0.0011 & 0.0110 & 0.0020 & 0.0055 & 0.6921 & 3.2511 & 0.083 \\
\hline MT 15 & 2.3647 & 0.0000 & 4.0000 & 0.0000 & 0.0005 & 0.0029 & 0.0010 & 0.0043 & 0.7429 & 3.1118 & 0.037 \\
\hline
\end{tabular}

conditions for three phase equilibria (aqueous solution+Srp-Nep+Ker-Pim, etc.).

The stability diagram delimits the stability field of each Ni-bearing phyllosilicate and quartz. For each field, only one of these solids is in equilibrium. Along the

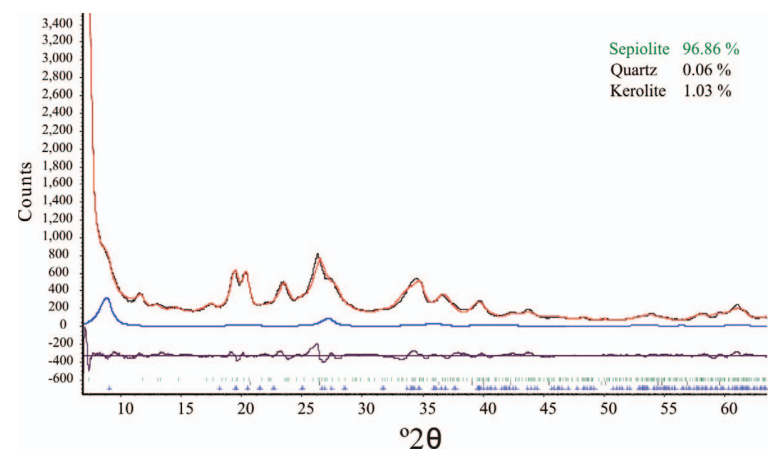

Figure 9. Powder XRD pattern of a mixture of Ker (hydrated talc)-Pim (hydrated willemseite) and Sep-Fal (sample F3 from Falcondo Mine). The measured profile was simulated (continuous line, Rietveld method); the bottom line is the difference between measured and calculated profiles; small vertical bars indicate the positions of Bragg reflections. The detached continuous line is the calculated profile of kerolite. boundaries delimiting the fields (curves SK, KSep, SSep, and SepQ), two solids are in equilibrium with the solution. Three of these curves intersect at one point (coordinates: $-4.3938,14.0022$ ) which is an invariant point. The solids in equilibrium with the aqueous solution are three solid solutions with calculated compositions: $\mathrm{Srp}_{0.747}-\mathrm{Nep}_{0.253}, \mathrm{Ker}_{0.353}-\mathrm{Pim}_{0.647}$, and Sep $_{0.340}-\mathrm{Fal}_{0.660}$.

The proposed activity diagram combined with Lippmann diagrams for each solid solution allows the determination of the main parameters characterizing the solution and the solid in equilibrium, namely, the activity fractions of $\mathrm{Mg}$ and $\mathrm{Ni}$ in the solids and in the solution, and the silica activity in solution. With a proper speciation model, the amount of $\mathrm{Mg}, \mathrm{Ni}$, and $\mathrm{Si}$ in solution and the $\mathrm{pH}$ can all be obtained.

The exact position of the ends of the boundaries depends on the accuracy of all $\log \mathrm{K}$ values involved. The equilibrium constants used in this approach have two different origins: experimental for the $\mathrm{Mg}$ endmembers, and predicted for Ni phases. The differences between experimental values reported by different authors, or values calculated using different models result in a crude estimation of the errors involved. Whenever possible, the analyses of mixtures supposed to 
Table 6. Selected analyses of garnierites and mixtures of kerolite-pimelite and sepiolite-falcondoite solid solutions (s.s.).

\begin{tabular}{|c|c|c|c|c|c|c|c|c|c|c|c|c|}
\hline Label & $\mathrm{Na}$ & $\mathrm{Mg}$ & $\mathrm{Al}$ & $\mathrm{Si}$ & $\mathrm{K}$ & $\mathrm{Ca}$ & $\mathrm{Ti}$ & $\mathrm{Mn}$ & $\mathrm{Fe}$ & $\mathrm{Ni}$ & $\mathrm{Mg}+\mathrm{Fe}+\mathrm{Ni}$ & $\begin{array}{l}\text { Kerolite } \\
\text { fraction }\end{array}$ \\
\hline FAL3-1_8 & 0.0107 & 2.7178 & 0.1076 & 12.0000 & 0.0106 & 0.0000 & 0.0000 & 0.0000 & 0.0146 & 5.3362 & 8.0685 & 0.0685 \\
\hline FAL3-1_11 & 0.0188 & 3.8942 & 0.0885 & 12.0000 & 0.0309 & 0.0000 & 0.0000 & 0.0041 & 0.0146 & 4.5489 & 8.4577 & 0.4577 \\
\hline FAL3-1_16 & 0.0337 & 1.9725 & 0.0785 & 12.0000 & 0.0369 & 0.0000 & 0.0000 & 0.0000 & 0.0000 & 6.4953 & 8.4678 & 0.4678 \\
\hline FAL3-1_18 & 0.0328 & 2.0216 & 0.0917 & 12.0000 & 0.0086 & 0.0000 & 0.0025 & 0.0029 & 0.0076 & 6.0767 & 8.1059 & 0.1059 \\
\hline FAL3-1_23 & 0.0053 & 2.5447 & 0.1127 & 12.0000 & 0.0105 & 0.0000 & 0.0062 & 0.0093 & 0.0103 & 5.5845 & 8.1395 & 0.1395 \\
\hline FAL3-1_24 & 0.0054 & 2.3785 & 0.1047 & 12.0000 & 0.0071 & 0.0000 & 0.0000 & 0.0000 & 0.0000 & 5.7606 & 8.1392 & 0.1392 \\
\hline GAR $1-4 \quad 10$ & 0.0040 & 2.8112 & 0.0000 & 12.0000 & 0.0020 & 0.0109 & 0.0000 & 0.0000 & 0.0000 & 5.6732 & 8.4844 & 0.4844 \\
\hline GAR 1-4_11 & 0.0040 & 2.3417 & 0.0000 & 12.0000 & 0.0050 & 0.0221 & 0.0060 & 0.0022 & 0.0019 & 6.1426 & 8.4862 & 0.4862 \\
\hline GAR 1-5_1 & 0.0030 & 3.3612 & 0.0000 & 12.0000 & 0.0000 & 0.0118 & 0.0000 & 0.0023 & 0.0041 & 5.0880 & 8.4533 & 0.4533 \\
\hline GAR 1-5_1n & 0.0030 & 2.7640 & 0.0120 & 12.0000 & 0.0020 & 0.0281 & 0.0020 & 0.0000 & 0.0059 & 5.7792 & 8.5491 & 0.5491 \\
\hline
\end{tabular}

precipitate in equilibrium were used as a constraint to reduce the choice between different reported or calculated $\log \mathrm{K}$ values.

The boundary between Srp-Nep and Ker-Pim fields (curve SK) displayed a pronounced change of slope. From the mid point to the $\mathrm{Mg}$ end, this boundary was almost parallel to the $\log \left(a_{\mathrm{SiO}_{2}(\mathrm{aq})}\right)$ axis, so that an increase in the activity of $\mathrm{Ni}$ in solution may favor the precipitation of Ker-Pim s.s., because the activity and activity ratio of $\mathrm{Ni}^{2+}$ increased downward on the diagram. The mixtures of Srp-Nep+Ker-Pim, fell in a field where the variable $\log \left(\left(a_{\mathrm{Mg}^{2+}}+a_{\mathrm{Ni}^{2+}}\right) /\left(a_{\mathrm{H}^{+}}\right)^{2}\right)$ was $>13.75$, with a $\mathrm{Ni} / \mathrm{Mg}$ ratio in solution of $10^{-5}-10^{-4}$ and calculated $\mathrm{pH}$ of $\sim 9.2$. The section of the SK boundary between the invariant point and the serpentine-kerolite intercept was metastable, running almost coincidental with, but below, the stable SSep boundary. For $\log \left(\left(a_{\mathrm{Mg}^{2+}}+a_{\mathrm{Ni}^{2+}}\right) /\left(a_{\mathrm{H}^{+}}\right)^{2}\right)$ values of $<13$, in the Ni-rich portion, the boundary SK was parallel to the vertical axis, and only the activity of silica determined the type of solid solution that precipitates. This was also the case for the next boundary between Ker-Pim and Sep-Fal (curve KSep) which drew an almost straight vertical line at $\log \left(a_{\mathrm{SiO}_{2} \text { (aq) }}\right)=-4.5$. The portion of the Srp-Nep field limiting with the Sep-Fal field was very narrow (boundary curve SSep), making the co-precipitation of these minerals less probable. In fact, coexistence of these two solid solutions was not observed in any of the samples.

Many processes leading to the formation of garnierites depend on factors not treated in this work (kinetic, climatic, hydrologic, tectonic, etc.). The stability diagram constructed (Figure 6) suggested, however, that two main temporal and spatial trends were related to the formation of Ni-enriched supergene phases. An increase in $\mathrm{Ni}^{2+}$ in the solutions percolating through or contained within the altered parent rock may be explained by one or the other of these two mechanisms, e.g. the leaching of $\mathrm{Ni}$ from goethite in the limonitic horizon by meteoric waters, and the repeated cycle of congruent dissolution of Ni-poor phyllosilicates followed by equilibrium precipitation of a phyllosilicate, slightly richer in $\mathrm{Ni}$. On the other hand, an increase in the silica activity may have occurred with the formation of a great variety of different forms of silicification (Golightly, 1981; Freyssinet et al., 2005; Trescases, 1975). Soler et al. (2008) observed in flow-through dissolution experiments of garnierites at low $\mathrm{pH}$ that the initial aqueous ratios of $\mathrm{Mg} / \mathrm{Si}$ and $(\mathrm{Mg}+\mathrm{Ni}) / \mathrm{Si}$ were three times greater than in the solid. After $900 \mathrm{~h}$, these ratios decreased to values only slightly above those of the dissolving garnierite. For higher $\mathrm{pH}$ values, the ratios in solution were always a little higher than in the dissolving phase. Preferential release of $\mathrm{Mg}$ over $\mathrm{Si}$ has been observed in $\mathrm{Mg}$ phyllosilicates previously (see Soler et al., 2008). Jurinski and Rimstidt (2001) observed the formation of a silica-rich surface on dissolving mineral grains. These experiments highlighted the fact that, for short dissolving events (i.e. a short period of rain), the dissolution of Ni-bearing phyllosilicates would not be stoichiometric with respect to the $(\mathrm{Mg}+\mathrm{Ni}) / \mathrm{Si}$ ratios but would be stoichiometric with respect to the $\mathrm{Mg} / \mathrm{Ni}$ ratio. As a result, significant amounts of silica might accumulate and remain available until changes in $\mathrm{pH}$ allow its mobilization. In turn, the supply of silica to aqueous solutions explains the increase in the silica activity and the evolution of garnierites from $\mathrm{Ni}$-serpentines to $\mathrm{Ni}$ sepiolites. In summary, the evolution of garnierites, as shown in the stability diagram (Figure 6), may be depicted as a trend pointing downward (Ni enrichment) and to the right (increase in silica activity).

\section{CONCLUSIONS}

Garnierites are very often composed of an intimate mixture of Ni-enriched phyllosilicates which include serpentine-népouite, kerolite-pimelite, and sepiolitefalcondoite solid solutions. The variable and intricate 
textures on a scale of only tens of microns (massive, accordion-like, layered, brecciated, etc.) represent an additional barrier to understanding the formation and evolution of these ore minerals. New insights were gained on the basis of the equilibrium thermodynamics approach presented above.

The dissolution equilibrium constants for pure $\mathrm{Ni}$ end-members népouite, pimelite, and falcondoite were derived following the method proposed by Nriagu (1975). These $\log \mathrm{K}$ values, together with selected experimental dissolution constants for pure $\mathrm{Mg}$ endmembers (serpentine, kerolite, and sepiolite) drawn from the literature, constitute a useful array of thermodynamic data.

The $\log \mathrm{K}$ values for the six $\mathrm{Mg}-\mathrm{Ni}$ end-members allows the calculation of the solidus and solutus curves of the Lippmann diagrams for the solid solutions serpentine-népouite, kerolite-pimelite, and sepiolite-falcondoite, assuming ideal solid solutions.

In $\mathrm{Ni}$ laterite soils, the mechanism of supergene enrichment consists of congruent dissolution of Ni-poor primary minerals followed by near-equilibrium precipitation of secondary Ni-enriched hydrated phyllosilicates. This was illustrated readily using Lippmann diagrams. This mechanism can operate through several cycles of congruent dissolution-equilibrium precipitation. The percolating aqueous solutions can also be enriched in Ni by the leaching of goethite.

The stability fields of each solid solution and the boundaries between them can be represented in [log $\left.a_{\mathrm{SiO}_{2}(\mathrm{aq})}, \log \left(\left(a_{\mathrm{Mg}^{2+}}+a_{\mathrm{Ni}^{2+}}\right) /\left(a_{\mathrm{H}^{+}}\right)^{2}\right)\right]$ diagrams. These activity diagrams, combined with Lippmann diagrams provide an almost complete characterization of the aqueous and solid(s) solution(s) in equilibrium.

After congruent dissolution of primary Ni-bearing minerals, the poor mobility of silica leads to progressive silicification within the laterite profile. The silica activity increases with time and through the profile, reaching saturation or supersaturation levels. The precipitation of $\mathrm{Ni}$ ore is then characterized by a succession of mineral phases progressively enriched in $\mathrm{Ni}$ and with more Si. Secondary Ni serpentines are the first phases to precipitate, followed by $\mathrm{Ni}$-kerolite and $\mathrm{Ni}$-sepiolite-like minerals.

\section{ACKNOWLEDGMENTS}

This research was supported financially by the Spanish projects CGL2006-07384 and CGL2009-10924 and grant 2009-SGR444 of the Catalonian Government. Paul Golightly and an anonymous reviewer are acknowledged for their constructive criticism which improved the manuscript. JAP and JFL gratefully acknowledge the help and hospitality extended by the staff at FalcondoXSTRATA mine. In particular they thank Francisco Longo for his help in collecting the garnierites at Falcondo Mine. The authors also acknowledge the assistance of $\mathrm{X}$. Llovet (Centres Científics i Tecnolgics of the Universitat de Barcelona) for his assistance with the electron micoprobe analyses.

\section{REFERENCES}

Brand, N.W., Butt, C.R.M., and Elias, M. (1998) Nickel laterites: classification and features. AGSO Journal of Australian Geology and Geophysics, 17, 81-88.

Bricker, O.P., Nesbitt, H.W., and Gunter, W.D. (1973) The stability of talc. American Mineralogist, 58, 64-72.

Brindley, G.W. and Hang, P.T. (1973) The nature of garnierites - I. Structures, chemical composition and color characteristics. Clay and Clay Minerals, 21, 27-40.

Brindley, G.W. and Maksimovic, Z. (1974) The nature and nomenclature of hydrous nickel-containing silicates. Clay Minerals, 10, 271-277.

Brindley, G.W. and Wan, H.M. (1975) Composition structures and thermal behavior of nickel containing minerals in the lizardite-népouite series. American Mineralogist, 60 , 863-871.

Brindley, G.W., Bish, D.L., and Wan, H.M. (1977) The nature of kerolite, its relation to talc and stevensite. Mineralogical Magazine, 41, 443-452.

Brindley, G.W., Bish, D.L., and Wan, H.M. (1979) Compositions, structures and properties of nickel containing minerals in the kerolite-pimelite series. American Mineralogist, 64, 615-625.

Christ, C.L., Hostetler, P.B., and Siebert, R.M. (1973) Studies in the system $\mathrm{MgO}-\mathrm{SiO}_{2}-\mathrm{CO}_{2}-\mathrm{H}_{2} \mathrm{O}$ (III): The activityproduct constant of sepiolite. American Journal of Science, 273, 65-83.

Cluzel, D. and Vigier, B. (2008) Syntectonic mobility of supergene nickel ores from New Caledonia (Southwest Pacific). Evidence from faulted regolith and garnierite veins. Resource Geology, 58, 161-170.

Evans, B.W. (2004) The serpentinite multisystem revisited: chrysotile is metastable. International Geology Review, 46, 479-506.

Freyssinet, Ph., Butt, C.R.M., and Morris, R.C. (2005) Oreforming processes related to lateritic weathering. Economic Geology $100^{\text {th }}$ Anniversary Volume, 681-722.

Gleeson, S.A., Butt, C.R., and Elias, M. (2003) Nickel laterites: A review. SEG Newsletter, 54, 11-18.

Glynn, P.D. and Reardon, E.J. (1990) Solid-solution aqueoussolution equilibria: thermodynamic theory and representation. American Journal of Science, 290, 164-201.

Golightly, J.P. (1981) Nickeliferous Laterite Deposits. Economic Geology, 75 th Anniversary Volume, 710-735.

Golightly, J.P. (2010) Progress in understanding the evolution of nickel laterite. 2010 Society of Economic Geology, Inc. Special Publication, 15, 451-485.

Helgeson, H.C. (1969) Thermodynamics of hydrothermal systems at elevated temperatures and pressures. American Journal of Science, 169, 729-804.

Helgeson, H.C., Delany, J.M., Nesbitt, H.W., and Bird, D.K. (1978) Summary and critique of the thermodynamic properties of rock-forming minerals. American Journal of Science, 278-A, 227 pp.

Hostetler, P.B. and Christ, C.L. (1968) Studies in the system $\mathrm{Mg}-\mathrm{SiO}_{2}-\mathrm{CO}_{2}-\mathrm{H}_{2} \mathrm{O} \mathrm{I}$ : the activity product constant of chrysotile. Geochimica et Cosmochimica Acta, 32, $482-497$

Jurinski, J.B. and Rimstidt, J.D. (2001) Biodurability of talc. American Mineralogist, 86, 392-399.

Lewis J.F., Draper, G., Proenza, J.A., Espaillat, J., and Jimenez, J. (2006) Ophiolite related ultramafic rocks (serpentinites) in the Caribbean region: a review of their occurrence, composition, origin, emplacement and $\mathrm{Ni}$ laterite soils formation. Geologica Acta, 4, 237-263

Lippman, F. (1980) Phase diagrams depicting the aqueous solubility of binary mineral systems. Neues Jahrbuch für Mineralogie Abhandlung, 139, 1-25. 
Manceau, A. and Calas, G. (1985) Heterogeneous distribution of nickel in hydrous silicates from New Caledonia ore deposits. American Mineralogist, 70, 549-558.

Manceau, A., Calas, G., and Decarreau, A. (1985) Nickelbearing clay minerals: I. Optical spectroscopic study of nickel crystal chemistry. Clay Minerals, 20, 367-387.

Manceau, A., Tamura, N., Celestre, R.S., MacDowell, A.A., Geoffroy, N., Sposito, G., and Padmore, H.A. (2003) Molecular-scale speciation of $\mathrm{Zn}$ and $\mathrm{Ni}$ in soil ferromanganese nodules from loess soils of the Mississippi Basin. Environmental Science \& Technology, 37, 75-80.

Mel'nik, Y.P. (1972) Thermodynamic Constants for the Analysis of Conditions of Formation of Iron Ores (in Russian). Institute of the Geochemistry and Physiscs of Minerals, Academy of Sciences, Ukranian S.S.R. Kiev, $193 \mathrm{pp}$.

Nriagu, J.O. (1975) Thermochemical approximation for clay minerals. American Mineralogist, 60, 834-839.

Pelletier, B. (1983) Localisation du nickel dans les minerais "garnieritiques" de Nouvelle-Caledonie. Sciences Géologique: Mémoires, 73, 173-183.

Phillips, S.L., Hale, F.V., Silvester, L.F., and Siegel, M.D. (1988) Thermodynamic Tables for Nuclear Waste Isolation. Aqueous Solution Database, Vol. 1. Lawrence Berkeley Laboratory, Berkeley, California and Sandia National Laboratories, Albuquerque, New Mexico, USA.

Prieto, M. (2009) Thermodynamics of solid solution-aqueous solution systems. Pp. 47-85 in: Thermodynamics and Kinetics of Water-Rock Interaction. Reviews in Mineralogy \& Geochemistry, 70, Mineralogical Society of America, Washington, D.C.

Proenza, J.A., Lewis, J.F., Galí, S., Tauler, E., Labrador, M., Melgarejo, J.C., Longo, F., and Bloise, G. (2008) Garnierite mineralization from Falcondo Ni-laterite deposit (Dominican Republic). Macla, 9, 197-198.

Reddy, B.J., Frost, R.L., and Dickfos, M.J. (2009) Characterisation of $\mathrm{Ni}$ silicate-bearing minerals by UVvis-NIR spectroscopy. Effect of $\mathrm{Ni}$ substitution in hydrous Ni-Mg silicates. Spectrochimica Acta, A71, 1762-1768.

Soler, J.M., Cama, J., Galí, S., Meléndez, W., Ramírez, A., and Estanga, J. (2008) Composition and dissolution kinetics of garnierite from the Loma de Hierro Ni-laterite deposit, Venezuela. Chemical Geology, 249, 191-202.

Springer, G. (1974) Compositional and structural variations in garnierites. The Canadian Mineralogist, 12, 381-388.
Springer, G. (1976) Falcondoite, nickel analogue of sepiolite. The Canadian Mineralogist, 14, 407-409.

Stoesell, R.K. (1988) $25^{\circ} \mathrm{C}$ and $1 \mathrm{~atm}$ dissolution experiments of sepiolite and kerolite. Geochimica et Cosmochimica Acta, 52, 365-374.

Tauler, E., Proenza, J.A., Galí, S., Lewis, J.F., Labrador, M., García-Romero, E., Suarez, M., Longo, F., and Bloise, G. (2009) Ni-sepiolite-falcondoite in garnierite mineralization from the Falcondo Ni-laterite deposit, Dominican Republic. Clay Minerals, 44, 435-454.

Tardy, Y. and Duplay, J. (1992) A method of estimating the Gibbs energies of formation of hydrated and dehydrated clay minerals. Geochimica et Cosmochimica Acta, 56, 3007-3029.

Tardy, Y. and Garrels, R.M. (1974) A method of estimating the Gibbs energies of formation of layer silicates. Geochimica et Cosmochimica Acta, 38, 1101-1116.

Trescases, J.J. (1975) L'évolution géochimique supergène des roches ultrabasiques en zone tropicale: Formations des gisements nickeliferes de Nouvelle Calédonie. Editions ORSTOM, Paris, 259 pp.

Villanova-de-Benavent, C., Nieto, F., Proenza, J.A., and Galí, S. (2011a) Talc- and serpentine-like "garnierites" from Falcondo Ni-laterite deposit (Dominican Republic): a HRTEM approach. Macla, 15, 197-198.

Villanova-de-Benavent, C., Proenza, J.A., Galí, S., Tauler, E., Lewis, J.F., and Longo, F. (2011b) Talc- and serpentine-like "garnierites" in the Falcondo Ni-laterite deposit, Dominican Republic. 'Let's talk ore deposits', 11th Biennial Meeting SGA 2011, Antofagasta, Chile, 3 pp.

Vitovskaya, I.V., Berkhin, S.I., and Yashina, R.S. (1969) The serpentine component of nickel silicates. Doklady Akademie Nauk SSSR, 189, 160-162.

Wagman, D.D., Evans, W.H., Parker, U.B., Halow, I., Bailey S.M., and Schumm, R.H. (1968) Selected values of chemical thermodynamic properties. National Bureau of Standards Technical Note, 270-3 (1968), 270-4 (1969).

Wells, M.A., Ramanaidou, E.R., Verrall, M., and Tessarolo, C. (2009) Mineralogy and crystal chemistry of "garnierites" in the Goro lateritic nickel deposit, New Caledonia. European Journal of Mineralogy, 21, 467-483.

(Received 27 October 2011; revised 21 March 2012; Ms. 626; A.E. W.D. Huff) 